Article

\title{
Geochemical Significance of Clay Minerals and Elements in Paleogene Sandstones in the Center of the Northern Margin of the Qaidam Basin, China
}

\author{
Guoqiang Sun $1,2, * \mathbb{C}$, Meng Wang ${ }^{1,3}$, Jiajia Guo ${ }^{4}$, Yetong Wang ${ }^{1,3}$ and Yongheng Yang ${ }^{1,3}$ \\ 1 Northwest Institute of Eco-Environment and Resources, Chinese Academy of Sciences, \\ Lanzhou 730000, China; wangmeng17@mails.ucas.ac.cn (M.W.); wangyetong16@mails.ucas.edu.cn (Y.W.); \\ yangyongheng17@mails.ucas.ac.cn (Y.Y.) \\ 2 Key Laboratory of Petroleum Resources, Lanzhou 730000, China \\ 3 University of Chinese Academy of Sciences, Beijing 100049, China \\ 4 Research Institute of Petroleum Exploration and Development-Northwest, Petrochina, \\ Lanzhou 730020, China; guojiajia123@petrochina.com.cn \\ * Correspondence: sguoqiang@lzb.ac.cn; Tel.: +86-0931-496-0858
}

Received: 24 April 2020; Accepted: 30 May 2020; Published: 31 May 2020

\begin{abstract}
The average thickness of Paleogene sandstones reaches about 3000-4000 m at the northern margin of the Qaidam Basin. However, the provenance and sedimentary environment of these sandstones are uncertain; thus, more comprehensive research is needed. Integrated research is conducted on the provenance and weathering process based on petrographic characteristics, clay minerals, and geochemical compositions of sandstones in the center of the northern Qaidam Basin. The results of lithofacies analysis show that the Paleogene sandstones were mainly derived from an active continental magmatic arc, subduction accretion, or a fold-thrust belt. The average illite content in the Paleogene clay minerals is more than $50 \%$, followed by chlorite and smectite, which reflect climatic and environmental characteristics that were arid to semi-arid, whereas the characteristics of carbon-oxygen isotopes reveal a mainly freshwater sedimentary environment. The corrected chemical index of alteration (CIA $\mathrm{A}_{\text {corr }}$ ) is between 56.3 and 75.7, with an average value of 66.5. These results indicate that the provenance of the Paleogene sandstones in the center of the northern Qaidam Basin mainly formed under cold and dry climatic conditions and experienced limited chemical weathering with a small amount that underwent intermediate chemical weathering under warm and humid conditions.
\end{abstract}

Keywords: framework petrography; clay minerals; elements; Paleogene sandstones; sedimentary environment; Qaidam Basin

\section{Introduction}

Since the Cenozoic era, the collision between the Indian and Eurasian plates has caused the Qinghai-Tibet plateau to substantially rise [1]. The complex intra-continental deformation process has had a profound impact on environmental climate change, sedimentary tectonic evolution, and the source-sink system in the inland region of Asia, which has considerably affected environmental resources, especially the accumulation, migration, and transformation of oil and gas in the inner basins of the Qinghai-Tibet plateau [2-4]. The Qaidam Basin (Figure 1), bounded by the eastern Kunlun, Altun, and Qilian mountains, is the largest inland basin in the Qinghai-Tibet plateau and one of the most important oil-gas basins in China [5-7]. In recent years, hundreds of millions of tons of oil and gas fields have been successively discovered in the Kunbei fault step zone, Yingxiongling in the southwest margin of the basin, Dongping nose uplift structure, and Niudong slopes in the northwest 
of the basin [8]. However, the central part of the northern margin of the Qaidam Basin, which had an early breakthrough in oil and gas exploration in the basin, is developing slowly with no significant discoveries. Previous studies on the sedimentary system, reservoir genesis, and diagenetic evolution have investigated the central region of the northern margin of the Qaidam Basin [9]. However, a scarcity of studies on provenance and diagenesis and lack of scientific predictions regarding high-quality and lithologic reservoirs are key factors that presently restrict oil and gas exploration in this area.

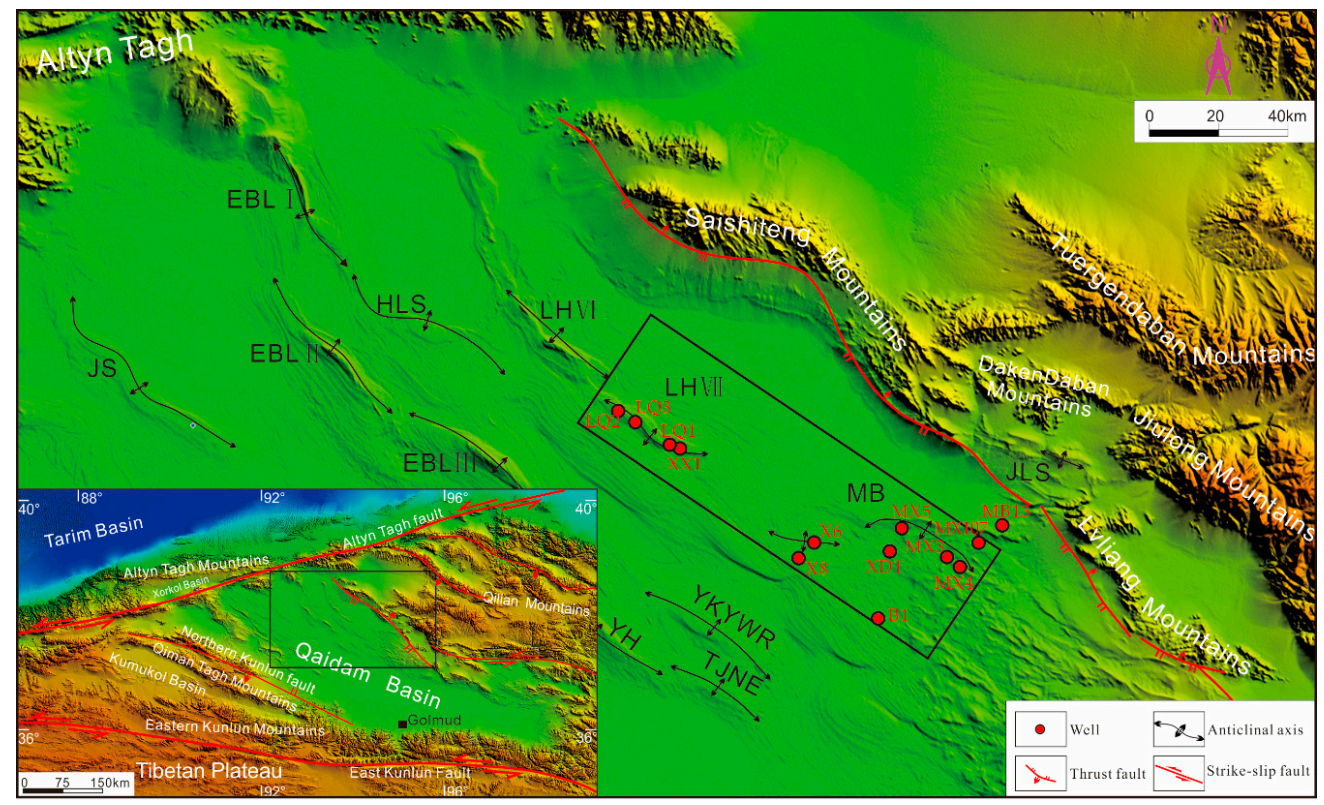

Figure 1. Structural map of the center of the northern Qaidam Basin. JS—Jianshan; EBLI-Eboliang I; EBL II-Eboliang II; EBL III-Eboliang III; HLS-Hulushan; LH VI-Lenghu VI; LH VII-Lenghu VII; NBX-Nanbaxian; MB-Mabei; YKYWR-Yikeyawuru; YH—Yahu; TJNR—Taijinaier.

Clay contents are widely distributed in various types of sediments and are the comprehensive products of sedimentation and diagenesis under certain climatic, hydrological, and provenance conditions, which are important for determining the sedimentary environment, paleoclimatic conditions, and diagenesis $[10,11]$. Therefore, the study of clay mineral contents and their combination provides important information for understanding the provenance, paleoclimate, sedimentary environment, and diagenetic characteristics for reproducing depositional and diagenetic processes [12]. The fluctuation of sediment chemistry is a common method for studying environmental change [13]. Different environmental conditions have different effects on the decomposition, migration, and enrichment of various elements with different properties [14]. Therefore, the change of the element contents in the sediment can largely reflect the sediment in the sedimentary source and change of environmental conditions [15]. Therefore, it is possible to analyze the provenance properties, sedimental-diagenetic environment, and paleoclimate conditions of sedimentary rocks by studying the characteristics of clay mineral assemblages and contents of major and trace elements and their ratios in sedimentary rocks. In this study, we analyzed core samples from key drill wells in the central part of the northern Qaidam Basin margin to study their provenance properties and sediment-diagenetic environment. The results provide data for future use in oil and gas exploration.

\section{Geologic Setting}

Based on tectonic geological analysis of the northwest region of China, regardless of the complexity of the tectonic evolution before the Mesozoic, the subduction and reduction of oceanic crust in the entire northwest region and subsequent collisional orogenic action between the continental lithospheric plates completed by the end of the Triassic [16]. Although the formation time and mode of the peripheral fault 
zones in the Qaidam Basin differ, the collisional effects of the Eastern Kunlun fault zone completed in the Permian and the main orogenic and uplift periods with relative lag ended by the end of the Middle Triassic [17,18]. The South Qilian fault zone mainly represents the uplift and orogeny associated with closure during the Caledonian [19-22]. Starting in the Triassic, the northwest region entered a land-evolution stage, and the Qaidam block inherited characteristics of the late Paleozoic fault-block continental apron. During the Indo-China epoch, accompanied by the closure of the circumferential trough, the fault block activity of the symmetrical continental uplift intensified. During the Yanshan movement, the Meso-Tethys Ocean continued to expand north and south, and the northern fault block belt of the Qaidam Basin in the circumference of the extrusion dynamic field was continuously uplifted. However, because of differences in the tectonic position and nature of the fault block, the uplift speed of each fault block also differed and the area with relatively slow uplift gradually developed into a depression-type fault block [23].

The Cenozoic Paleogene-Neogene sandstones are mainly composed of continental sedimentary facies [24,25], which were deposited mainly in braided-river delta-lacustrine environments and include fluvial, deltaic, and lacustrine sedimentary deposits (conglomerate, sandstone, siltstone, and mudstone). The lithology changed substantially over the Paleogene and has the characteristics of a progradational sequence. Interactive deposits of coarse clastic sandstones and fine clastic sandstones of unequal thickness indicate that the hydrodynamic conditions changed more frequently in the Neogene. Based on the results of previous studies on the stratigraphic framework of the northern Qaidam Basin [26-28], the Paleogene-Neogene can be divided into five units. These five stratigraphic units are listed in Figure 2.

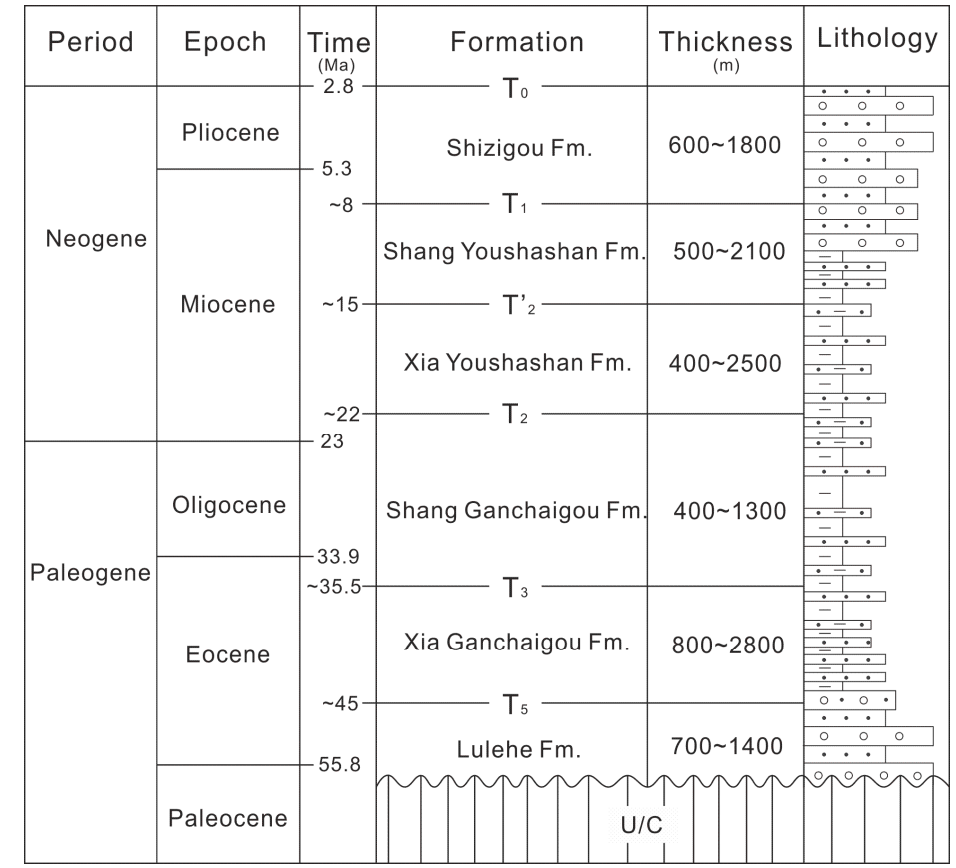

Figure 2. Paleogene-Neogene stratigraphy, seismic reflectors $\left(\mathrm{T}_{0}-\mathrm{T}_{5}\right)$, thickness, and representative lithological column of the northern Qaidam Basin [25].

\section{Materials and Methods}

Samples were obtained from cores of eight exploration wells (Figure 1) from the Lulehe Formation and Xiaganchaigou Formation in the center of the northern Qaidam Basin. Sandstone is the main lithology of the samples, followed by siltstone.

X-ray diffraction (XRD) was performed following techniques outlined by the Standard of Petroleum and Natural Gas Industry of the People's Republic of China (SY/T 5163-2010 Analysis Method for 
Clay Minerals and Ordinary Non-Clay Minerals in Sedimentary Rocks by the X-Ray Diffraction). XRD patterns were obtained using an Ultama IV X-ray diffractometer (Rigaku, Tokyo, Japan) equipped with a rotating anode, using $\mathrm{Cu}-\mathrm{K}_{\alpha}$ radiation, operating at $40 \mathrm{kV}$ and $40 \mathrm{~mA}$, taking DS (divergence slit) $=$ SS (scattering slit) $=1^{\circ}$, and RS (receiving slit) $=0.15 \mathrm{~mm}$. The scanning angle ranged from $2^{\circ}$ to $52^{\circ}$ with a step interval of $0.02^{\circ}$ at a rate of $4^{\circ}(2 \theta) / \mathrm{min}$. Sample powder was placed in a $500-\mathrm{mL}$ or 1-L beaker with distilled water to soak for 1 day. To remove organic matter, $15 \%$ hydrogen peroxide solution was added the beaker over 1 day. Then, dilute $0.5 \%$ hydrochloric acid was added to the beaker and stirred for $1 \mathrm{~h}$. The treatment was repeated until the reaction to remove carbonate had completed. Then, the treated samples were thoroughly washed with and soaked in deionized water. A few drops of $5 \%$ sodium hexametaphosphate solution were added to the soaked samples and allowed to sit for 5-10 min. Then, an ultrasound was used to disperse and fully suspend the clay. The suspension of clay particle sizes $<2 \mu \mathrm{m}$ was drawn in the upper $2-5 \mathrm{~cm}$ range and centrifuged to separate the suspension ( $3500 \mathrm{r} / \mathrm{min}$ for $10 \mathrm{~min}$ ) to precipitate the clay particles. The upper layer of water was removed, and the clay was set into oriented sections. After separation and extraction, $40 \mathrm{mg}$ of dry clay and $7 \mathrm{~mL}$ of distilled water were combined, well agitated, dispersed by ultrasonic vibration for $10 \mathrm{~min}$, and then applied to a glass slide to dry naturally and make a oriented section ( $\mathrm{N}$ section). The $\mathrm{N}$ section was placed on a sedimentation mount for $\mathrm{X}$-ray scanning. Then, the tested $\mathrm{N}$ section was placed in a desiccator containing ethylene glycol saturated steam and held at $40-50{ }^{\circ} \mathrm{C}$ for $7 \mathrm{~h}$. After cooling to room temperature, an ethylene glycol saturated section (EG section) was prepared and subjected to X-ray diffraction analysis. After measuring the XRD pattern, the EG section was placed in a muffle furnace, heated to $550^{\circ} \mathrm{C}$, and held at constant temperature for $2 \mathrm{~h}$. After cooling naturally to room temperature, a heating section (T section) was prepared, and X-ray diffraction analysis was performed immediately.

Prior to testing, a $1 \%$ dilute hydrochloric acid solution was used for drop testing. Hydrochloric acid ( $1 \%$ solution) was dropped on the rock in situ. Calcite reacts violently with abundant bubbles, whereas dolomite reacts slowly with only a few bubbles. The iron-bearing calcite reaction is between calcite and dolomite [29]. The carbonate cement of Paleogene sandstone in the north Qaidam Basin margin is mainly calcite and nearly free of dolomite and iron calcite [30]. Therefore, the carbonate (i.e., calcite) cement can preliminarily be determined according to the effervescence strength. The combination of optical microscope, scanning electron microscopy (SEM), and X-ray microanalysis ensured that samples with high carbonate cement content were selected for testing. The instrument used for determining stable carbon and oxygen isotope concentrations was a stable isotope mass spectrometer, MAT252, produced by Finnegan, Germany. The samples were gently powdered in an agate mortar, passed through a 100-200 mesh sieve, and then packed in a cavity mount for bulk mineral analyses. The phosphoric acid method was adopted for sample treatment. Trace samples were added to $100 \%$ phosphoric acid for reaction at $90^{\circ} \mathrm{C}$. Then, the generated $\mathrm{CO}_{2}$ was dried and dehydrated. Isotopes were measured with the MAT252 mass spectrometer. Carbon and oxygen isotope test results for all samples were determined with respect to the PDB standard [30]. This analysis was completed at the Key Laboratory of Oil and Gas Resources Research of the CAS (Chinese Academy of Sciences).

The morphology of clay mineral particles was characterized by SEM (Merlin Compact, Zeiss, Oberkochen, Germany) at the Key Laboratory of Oil and Gas Resources Research of the CAS with a resolution of $0.8 \mathrm{~nm}$.

Before elemental analysis, the samples were observed under a microscope for mineral composition and structure to ensure that the samples used for elemental geochemical analysis were not altered, secondarily mineralized, or secondarily weathered. Approximately 150 sandstone samples were selected and ground into thin slices. The mineral constituents, grain size, sorting, and roundness of these samples were observed and recorded using a polarizing microscope. Each thin section was analyzed using the Gazzi-Dickinson method [31]. Medium- to coarse-grained sandstones were used for point counting to minimize the grain-size effects [32]. A minimum of 400 points were counted per sample. All samples were ground with a pollution-free crusher and passed through 200-mesh sieves 
and then baked in an oven for about $3 \mathrm{~h}$ to remove moisture for accurate weighing. Determination of the main elements was carried out by a 3080E3X fluorescence spectrometer produced by the Japanese Science Company. Samples were sealed and dissolved by $\mathrm{HF}+\mathrm{HNO}_{3}$ and analyzed by laser coupled plasma mass spectrometry. The major and trace element analyses were both completed at the Key Laboratory of Oil and Gas Resources Research of the CAS.

\section{Sandstone Framework Petrography}

\subsection{Texture and Composition}

The lithology of the Lulehe Formation $\left(\mathrm{E}_{1+2}\right)$ varies substantially with brown conglomerate and brownish-red pebbly sandstone at the bottom that gradually fine upward into sandstone (Figure 3a). The gravel in the bottom conglomerate is poorly rounded and poorly sorted, and it contains a large amount of mudstone matrix (Figure 3b). The lower part of the Xiaganchaigou Formation $\left(E_{3}\right)$ is dominated by conglomerate and sandy conglomerate, and the gravel sorting is poor but the rounding is better and there is less mudstone matrix (Figure 3c). The middle and upper parts of the Xiaganchaigou Formation $\left(\mathrm{E}_{3}\right)$ contain more sandstone with a wide range of particle sizes and thicknesses. The sandstone is mainly brown, brown-gray, and gray, with tabular cross-bedding and undulating bedding developed in the bedding structure, and basal scour surfaces are common. The mudstone is mainly developed at the top of the Xiaganchaigou Formation and is mostly brown-red with plant debris and silt-grade debris. The mudstone thickness varies greatly with common parallel bedding (Figure 3d).

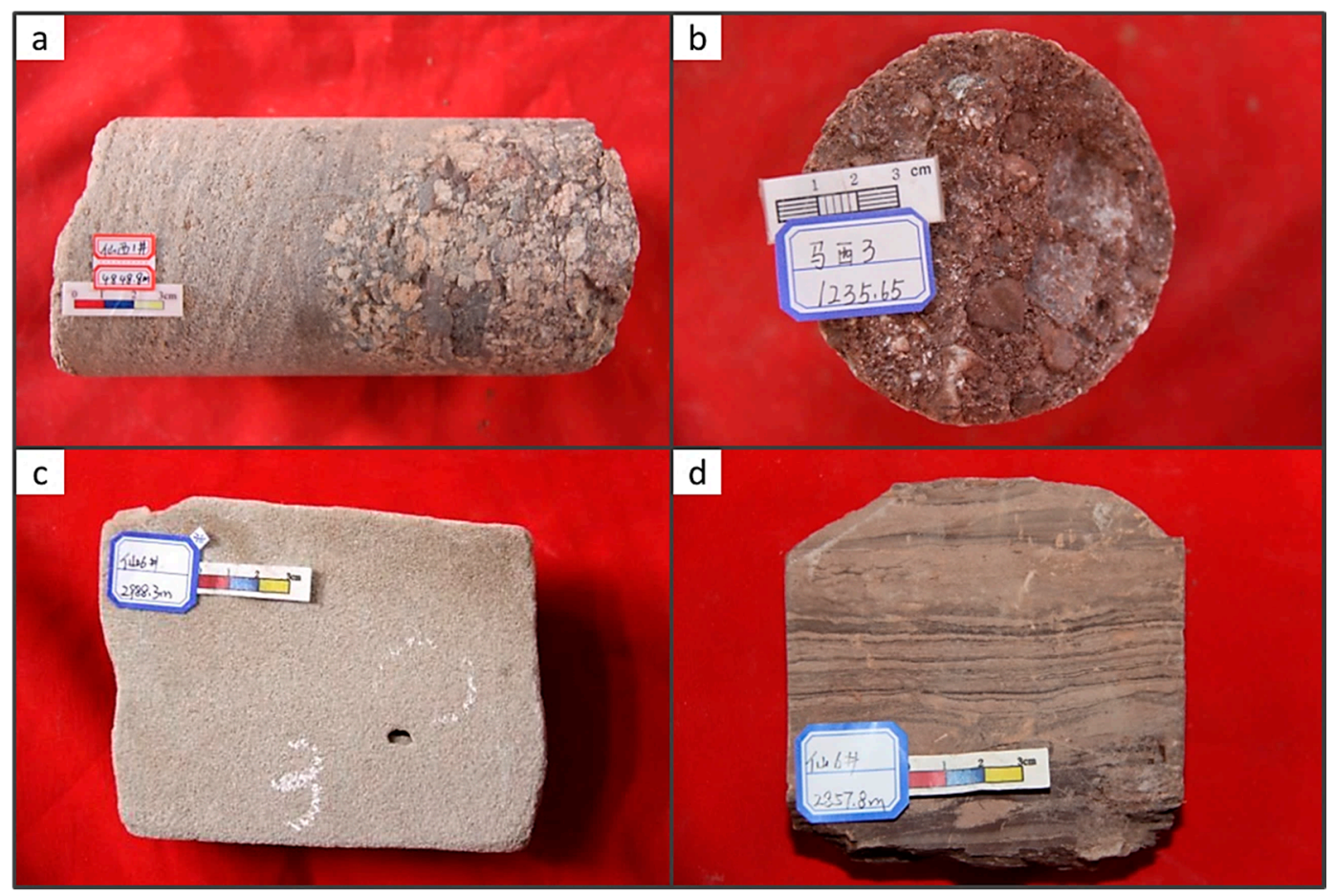

Figure 3. Characteristics of Paleogene drilling cores from the center of the northern Qaidam Basin. (a) XX1, Lulehe Formation $\left(\mathrm{E}_{1+2}\right), 4848.8 \mathrm{~m}$, brown conglomerate and brownish-red pebbly sandstone at the bottom, poorly sorted and rounded, fining upward; (b) MX3, Lulehe Formation $\left(\mathrm{E}_{1+2}\right), 1235.65 \mathrm{~m}$, brown-red conglomerate, poorly sorted, moderately well rounded; (c) X6, Xiaganchaigou Formation $\left(E_{3}\right)$, grayish-white medium sandstone, well sorted, well rounded; (d) X6, Xiaganchaigou Formation $\left(E_{3}\right)$, brown argillaceous siltstone with wave-ripple cross-bedding. 
Most of the Paleogene sandstones have subangular to subrounded and poorly sorted grains (Figure $4 \mathrm{a}-\mathrm{c}$ ), and the grains in only a few sandstones are subrounded to rounded and well-sorted (Figure $4 \mathrm{~d}$ ). The Paleogene sandstones contain a variety of minerals, including monocrystalline and polycrystalline quartz, carbonate, volcanic fragments, schist, K-feldspar, plagioclase, slate, and phyllite (Figure 4).

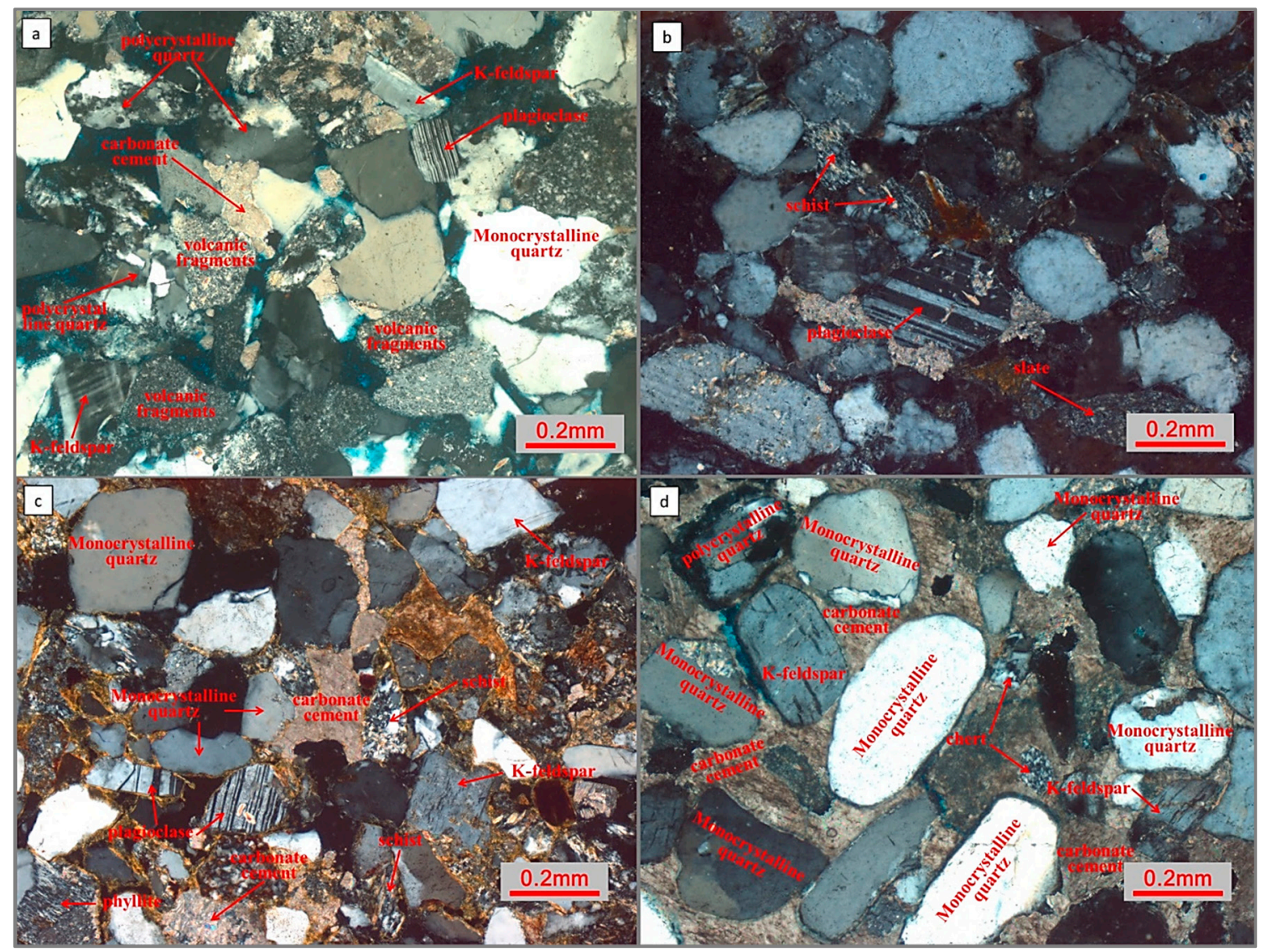

Figure 4. Representative photomicrographs of the lithic component of the Paleogene sandstones. (a) XX1, Xiaganchaigou Formation $\left(\mathrm{E}_{3}\right), 4212.14 \mathrm{~m}$, medium-fine lithic arkose with subangular grains, including plagioclase $(\mathrm{P})$ and K-feldspar $(\mathrm{K})$, a few volcanic fragments $(+) \times 100 ;(\mathbf{b})$ MX101, Xiaganchaigou Formation $\left(\mathrm{E}_{3}\right), 832.96 \mathrm{~m}$, medium-fine lithic arkose with subrounded-subangular grains, low-grade metamorphic rocks (e.g., schist and slate) $(+) \times 100$; (c) MB13, Xiaganchaigou Formation $\left(E_{3}\right), 1368.31$ m, medium-fine lithic arkose subrounded-subangular grains, including plagioclase $(\mathrm{P})$ and $\mathrm{K}$-feldspar (K), low-grade metamorphic rocks (e.g., schist and phyllite) and carbonate (C) (+) $\times 100$; (d) XD1, Xiaganchaigou Formation $\left(\mathrm{E}_{3}\right), 3085.61 \mathrm{~m}$, medium-fine lithic arkose with subrounded-rounded grains and high quartz abundance, including monocrystalline and polycrystalline quartz and a few chert fragments $(\mathrm{Ch}),(+) \times 100$.

\subsection{Detrital Analysis}

The results of detrital analysis are shown in Table 1 and Figure 5, illustrated in Qt-F-L, Qm-F-Lt, and Qp-Ls-Lv diagrams $(\mathrm{Qt}=$ total quartz grains, $\mathrm{F}=$ total feldspar grains, $\mathrm{L}=$ total unstable lithic fragments, $\mathrm{Qm}=$ monocrystalline quartz, $\mathrm{Lt}=$ total lithic fragments, $\mathrm{Qp}=$ polycrystalline quartz, Ls = sedimentary/metasedimentary lithic fragments, Lv = volcanic/metavolcanic lithic fragments) [31]. 
Table 1. Relative abundance of single compositional classes in the Paleogene sandstones.

\begin{tabular}{|c|c|c|c|c|c|c|c|c|c|c|}
\hline Well & $\begin{array}{l}\text { Buried Depth } \\
\text { (m) }\end{array}$ & $\begin{array}{c}\mathrm{L} \\
(\%)\end{array}$ & $\begin{array}{l}\mathrm{Qt} \\
(\%)\end{array}$ & $\begin{array}{c}F \\
(\%)\end{array}$ & $\begin{array}{l}\mathrm{Lt} \\
(\%)\end{array}$ & $\begin{array}{l}\text { Qm } \\
(\%)\end{array}$ & $\begin{array}{c}F \\
(\%)\end{array}$ & $\begin{array}{l}\text { Ls } \\
(\%)\end{array}$ & $\begin{array}{l}Q p \\
(\%)\end{array}$ & $\begin{array}{l}\text { Lv } \\
(\%)\end{array}$ \\
\hline \multirow{40}{*}{ XX1 } & 4111.55 & 24.14 & 49.99 & 25.87 & 50.85 & 23.28 & 25.87 & 37.31 & 52.52 & 10.17 \\
\hline & 4111.75 & 31.85 & 40.27 & 27.87 & 47.24 & 24.89 & 27.87 & 46.35 & 32.57 & 21.07 \\
\hline & 4112.11 & 34.72 & 39.49 & 25.79 & 51.40 & 22.81 & 25.79 & 52.11 & 32.45 & 15.44 \\
\hline & 4112.64 & 28.27 & 49.12 & 22.61 & 58.00 & 19.38 & 22.61 & 36.21 & 51.26 & 12.53 \\
\hline & 4112.95 & 32.36 & 38.31 & 29.33 & 47.41 & 23.26 & 29.33 & 51.19 & 31.75 & 17.06 \\
\hline & 4113.72 & 34.87 & 39.95 & 25.18 & 54.48 & 20.34 & 25.18 & 48.00 & 36.00 & 16.00 \\
\hline & 4114.10 & 35.42 & 38.28 & 26.31 & 53.45 & 20.24 & 26.31 & 51.11 & 33.75 & 15.14 \\
\hline & 4114.84 & 39.13 & 36.42 & 24.45 & 54.03 & 21.52 & 24.45 & 43.45 & 27.58 & 28.97 \\
\hline & 4115.32 & 30.90 & 47.95 & 21.14 & 62.59 & 16.26 & 21.14 & 32.48 & 50.63 & 16.89 \\
\hline & 4115.60 & 32.15 & 44.16 & 23.69 & 59.39 & 16.92 & 23.69 & 37.04 & 45.87 & 17.09 \\
\hline & 4115.83 & 31.50 & 46.12 & 22.38 & 60.21 & 17.41 & 22.38 & 34.42 & 47.69 & 17.90 \\
\hline & 4116.12 & 30.53 & 47.20 & 22.28 & 61.22 & 16.50 & 22.28 & 35.04 & 50.14 & 14.82 \\
\hline & 4116.52 & 30.71 & 42.42 & 26.87 & 52.01 & 21.11 & 26.87 & 42.44 & 40.96 & 16.61 \\
\hline & 4207.94 & 24.69 & 53.99 & 21.32 & 33.79 & 44.89 & 21.32 & 56.45 & 26.94 & 16.60 \\
\hline & 4208.41 & 13.81 & 50.08 & 36.11 & 18.22 & 45.67 & 36.11 & 69.93 & 24.24 & 5.83 \\
\hline & 4208.90 & 12.34 & 54.77 & 32.89 & 19.82 & 47.29 & 32.89 & 51.87 & 37.76 & 10.37 \\
\hline & 4209.48 & 25.13 & 51.75 & 23.12 & 36.67 & 40.21 & 23.12 & 41.12 & 31.47 & 27.41 \\
\hline & 4210.33 & 23.26 & 50.32 & 26.43 & 33.40 & 40.17 & 26.43 & 56.96 & 30.38 & 12.66 \\
\hline & 4210.97 & 22.64 & 54.72 & 22.64 & 36.20 & 41.16 & 22.64 & 51.18 & 37.45 & 11.37 \\
\hline & 4211.25 & 22.94 & 55.27 & 21.79 & 30.04 & 48.17 & 21.79 & 64.90 & 23.65 & 11.45 \\
\hline & 4211.82 & 21.60 & 54.52 & 23.88 & 29.51 & 46.62 & 23.88 & 65.51 & 26.79 & 7.71 \\
\hline & 4212.45 & 27.25 & 46.63 & 26.12 & 28.46 & 45.42 & 26.12 & 79.80 & 4.25 & 15.96 \\
\hline & 4212.97 & 21.02 & 55.75 & 23.23 & 28.10 & 48.67 & 23.23 & 62.99 & 25.20 & 11.81 \\
\hline & 4213.57 & 25.69 & 56.88 & 17.43 & 41.29 & 41.28 & 17.43 & 44.44 & 37.79 & 17.77 \\
\hline & 4214.57 & 23.88 & 53.27 & 22.85 & 30.43 & 46.73 & 22.85 & 64.85 & 21.50 & 13.65 \\
\hline & 4215.63 & 10.24 & 55.62 & 34.14 & 13.51 & 52.35 & 34.14 & 58.95 & 24.21 & 16.84 \\
\hline & 4847.08 & 25.48 & 32.49 & 42.04 & 26.12 & 31.84 & 42.04 & 73.15 & 2.47 & 24.38 \\
\hline & 4849.51 & 22.39 & 41.98 & 35.63 & 36.89 & 27.48 & 35.63 & 41.39 & 39.30 & 19.31 \\
\hline & 4850.39 & 23.53 & 48.59 & 27.88 & 49.46 & 22.66 & 27.88 & 31.71 & 52.43 & 15.86 \\
\hline & 4851.06 & 26.44 & 45.23 & 28.33 & 48.06 & 23.61 & 28.33 & 37.33 & 44.98 & 17.68 \\
\hline & 4851.46 & 23.63 & 49.24 & 27.13 & 51.86 & 21.01 & 27.13 & 27.00 & 54.43 & 18.56 \\
\hline & 4851.61 & 25.21 & 45.85 & 28.94 & 48.65 & 22.41 & 28.94 & 30.70 & 48.19 & 21.11 \\
\hline & 4852.37 & 21.00 & 45.01 & 33.99 & 39.01 & 27.00 & 33.99 & 38.44 & 46.18 & 15.38 \\
\hline & 4853.27 & 20.88 & 37.36 & 41.76 & 33.18 & 25.06 & 41.76 & 44.05 & 37.08 & 18.88 \\
\hline & 4853.55 & 20.10 & 44.49 & 35.41 & 41.62 & 22.97 & 35.41 & 32.19 & 51.72 & 16.09 \\
\hline & 4853.87 & 20.32 & 47.34 & 32.33 & 44.57 & 23.09 & 32.33 & 29.02 & 54.40 & 16.58 \\
\hline & 4854.44 & 24.35 & 40.57 & 35.07 & 41.55 & 23.38 & 35.07 & 42.20 & 41.38 & 16.41 \\
\hline & 4854.56 & 22.37 & 45.41 & 32.22 & 46.31 & 21.48 & 32.22 & 34.79 & 51.69 & 13.53 \\
\hline & 4855.35 & 22.41 & 40.92 & 36.67 & 38.89 & 24.44 & 36.67 & 47.15 & 42.38 & 10.48 \\
\hline & 4853.27 & 20.88 & 37.36 & 41.76 & 33.18 & 25.06 & 41.76 & 44.05 & 37.08 & 18.88 \\
\hline \multirow{16}{*}{ X6 } & 2158.50 & 19.00 & 47.00 & 34.00 & 22.09 & 38.37 & 39.53 & 54.55 & 42.42 & 3.03 \\
\hline & 2161.50 & 29.00 & 39.00 & 32.00 & 31.87 & 32.97 & 35.16 & 73.68 & 23.68 & 2.63 \\
\hline & 2222.50 & 16.00 & 56.00 & 28.00 & 20.00 & 45.00 & 35.00 & 41.67 & 55.56 & 2.78 \\
\hline & 2312.00 & 26.00 & 44.00 & 30.00 & 28.57 & 38.46 & 32.97 & 71.43 & 25.71 & 2.86 \\
\hline & 2330.50 & 28.00 & 43.00 & 29.00 & 31.11 & 36.67 & 32.22 & 71.05 & 26.32 & 2.63 \\
\hline & 2348.50 & 17.00 & 59.00 & 24.00 & 21.79 & 47.44 & 30.77 & 41.03 & 56.41 & 2.56 \\
\hline & 2355.50 & 19.00 & 49.00 & 32.00 & 21.84 & 41.38 & 36.78 & 56.25 & 40.63 & 3.13 \\
\hline & 2415.50 & 16.00 & 57.00 & 27.00 & 22.54 & 39.44 & 38.03 & 33.33 & 64.44 & 2.22 \\
\hline & 2438.50 & 21.00 & 49.00 & 30.00 & 25.30 & 38.55 & 36.14 & 52.63 & 44.74 & 2.63 \\
\hline & 2467.50 & 21.00 & 51.00 & 28.00 & 25.93 & 39.51 & 34.57 & 50.00 & 47.50 & 2.50 \\
\hline & 2479.00 & 21.00 & 52.00 & 27.00 & 26.92 & 38.46 & 34.62 & 46.51 & 51.16 & 2.33 \\
\hline & 2498.00 & 19.00 & 54.00 & 27.00 & 23.46 & 43.21 & 33.33 & 47.37 & 50.00 & 2.63 \\
\hline & 2538.00 & 16.00 & 57.00 & 27.00 & 21.92 & 41.10 & 36.99 & 34.88 & 62.79 & 2.33 \\
\hline & 2556.00 & 19.00 & 59.00 & 22.00 & 24.05 & 48.10 & 27.85 & 45.00 & 52.50 & 2.50 \\
\hline & 2628.50 & 21.00 & 58.00 & 21.00 & 26.25 & 47.50 & 26.25 & 48.78 & 48.78 & 2.44 \\
\hline & 2658.50 & 18.00 & 52.00 & 30.00 & 21.18 & 43.53 & 35.29 & 51.52 & 45.45 & 3.03 \\
\hline
\end{tabular}


Table 1. Cont.

\begin{tabular}{ccccccccccc}
\hline Well & $\begin{array}{c}\text { Buried Depth } \\
(\mathbf{m})\end{array}$ & $\begin{array}{c}\mathbf{L} \\
\mathbf{( \% )}\end{array}$ & $\begin{array}{c}\mathbf{Q t} \\
\mathbf{( \% )}\end{array}$ & $\begin{array}{c}\mathbf{F} \\
\mathbf{( \% )}\end{array}$ & $\begin{array}{c}\mathbf{L t} \\
\mathbf{( \% )}\end{array}$ & $\begin{array}{c}\mathbf{Q m} \\
\mathbf{( \% )}\end{array}$ & $\begin{array}{c}\mathbf{F} \\
\mathbf{( \% )}\end{array}$ & $\begin{array}{c}\mathbf{L s} \\
\mathbf{( \% )}\end{array}$ & $\begin{array}{c}\mathbf{Q p} \\
\mathbf{( \% )}\end{array}$ & $\begin{array}{c}\text { Lv } \\
\mathbf{( \% )}\end{array}$ \\
\hline \multirow{4}{*}{ X8 } & 2100.00 & 31.50 & 45.50 & 23.00 & 49.00 & 28.00 & 23.00 & 54.08 & 35.71 & 10.20 \\
& 2103.00 & 26.00 & 49.00 & 25.00 & 50.00 & 25.00 & 25.00 & 41.00 & 48.00 & 11.00 \\
& 2161.00 & 26.00 & 48.00 & 26.00 & 44.00 & 30.00 & 26.00 & 52.27 & 40.91 & 6.82 \\
& 2176.00 & 26.00 & 47.00 & 27.00 & 44.00 & 29.00 & 27.00 & 45.45 & 40.91 & 13.64 \\
& 2180.00 & 30.50 & 43.50 & 26.00 & 49.00 & 25.00 & 26.00 & 47.96 & 37.76 & 14.29 \\
\hline \multirow{4}{*}{ XD1 } & 2997.24 & 21.35 & 52.91 & 25.74 & 44.71 & 29.55 & 25.74 & 42.64 & 52.24 & 5.12 \\
& 2998.94 & 13.29 & 50.27 & 36.44 & 22.83 & 40.73 & 36.44 & 46.95 & 41.78 & 11.27 \\
& 3001.27 & 9.40 & 49.22 & 41.39 & 13.87 & 44.74 & 41.39 & 48.39 & 32.26 & 19.35 \\
& 3004.89 & 19.23 & 53.15 & 27.62 & 39.23 & 33.15 & 27.62 & 42.25 & 50.99 & 6.76 \\
& 3084.44 & 14.55 & 68.73 & 16.72 & 49.83 & 33.44 & 16.72 & 25.17 & 70.81 & 4.03 \\
& 3085.25 & 14.50 & 69.67 & 15.83 & 50.83 & 33.33 & 15.83 & 24.59 & 71.48 & 3.93 \\
& 3085.80 & 21.27 & 51.83 & 26.89 & 24.21 & 48.90 & 26.89 & 75.76 & 12.12 & 12.12 \\
& 3088.50 & 24.09 & 56.58 & 19.33 & 56.13 & 24.54 & 19.33 & 39.74 & 57.09 & 3.18 \\
& 3091.85 & 22.12 & 59.45 & 18.43 & 61.09 & 20.48 & 18.43 & 33.52 & 63.80 & 2.68 \\
\hline
\end{tabular}
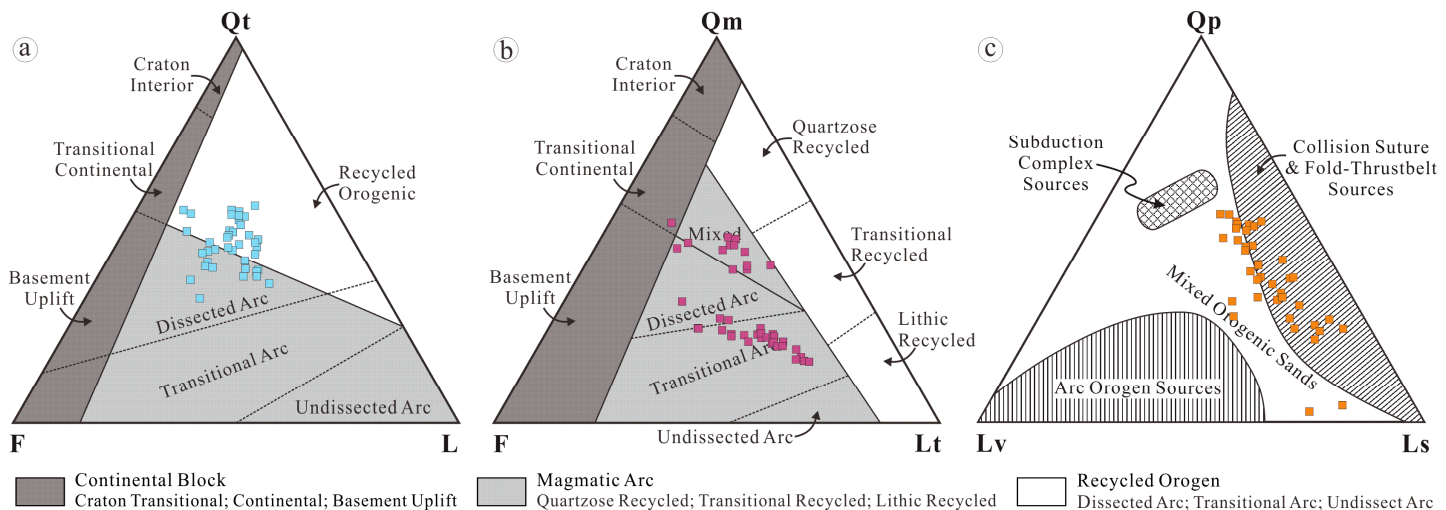

Figure 5. Ternary plots of sandstone framework grain compositions. (a) Q-F-L diagram; (b) Qm-F-Lt diagram; (c) Qp-Lvm-Lsm diagram. Provenance fields are from Dickinson [31].

The quartz content ranges from $32.5 \%$ to $69.7 \%$, with an average of $49.1 \%$ in these samples; monocrystalline quartz accounts for $63.5 \%$, and polycrystalline quartz accounts for $36.5 \%$ on average. Feldspars dominated by plagioclase constitute an average of $27.5 \%$ for all 69 samples from the Paleogene sandstones, with a range of $15.8 \%$ to $42.07 \%$ (Figure $4 b, c$ ). Lithic fragments range from $9.4 \%$ to $39.1 \%$, with an average of $23.4 \%$. The lithic component is represented by low-grade metamorphic rocks, such as slate, schist, and phyllite (Figure $4 \mathrm{~b}, \mathrm{c}$ ), followed by sedimentary rocks such as carbonate and sandstone (Figure 4c). Volcanic rock fragments were found in only a small number of samples (Figure 4a).

The compositional data for all samples suggest a recycled orogenic and dissected arc provenance (Figure 5a). However, in the Qm-F-Lt ternary diagram, the samples plot as mixed with dissected arc and transitional arc sources (Figure 5b). The samples mainly plot near the Ls pole in the Qp-Lv-Ls ternary diagram, which indicates that they were mainly from collision suture and fold-thrust belt sources. Only a relatively small portion was derived from mixed orogenic sands (Figure 5c).

\section{Clay Minerals}

Authigenic kaolinite mainly forms by feldspar leaching in an acidic medium, followed by the direct precipitation of pore water in the diagenetic stage [33-36], and it can also form by weathering and low-temperature hydrothermal metasomatism [37]. It is mainly distributed in the humid tropics and subtropics $[33,38]$ and it is an indicator mineral of weak acid leaching and strong chemical weathering [37,39]. Authigenic smectite usually forms in alkaline media poor in $\mathrm{K}^{+}$but rich in $\mathrm{Na}^{+}$ and $\mathrm{Ca}^{2+}[38,40]$, which is related to a cold climate. The contents of authigenic smectite are higher 
in sediments of temperate semi-humid zones [33] and decrease with the heat of the climate [39]. Chlorite is precipitated from $\mathrm{Mg}^{2+}$-rich pore water in relatively high temperature and strongly alkaline environments $[33,35]$. Generally, chlorite can only be preserved in areas with weak chemical weathering, which is completely opposite of the formation environment of kaolinite [41]. Illite mainly forms by the weathering of aluminosilicate minerals such as potash feldspar and mica under weak leaching in a $\mathrm{K}^{+}$-rich alkaline water medium $[33,38,42,43]$, or $\mathrm{Fe}^{2+}$ and $\mathrm{Mg}^{2+}$ in smectite are replaced by $\mathrm{Al}^{3+}$ and $\mathrm{K}^{+}$and dehydrated to form illite [35], which mainly occurs in dry and cold environments [44,45]. The existence of an illite-smectite mixed layer reflects the gradual transformation from smectite to illite in an alkaline environment rich in $\mathrm{K}^{+}$, and illite becomes more stable in a water environment with a high $\mathrm{K}^{+} / \mathrm{H}^{+}$ratio $[33,35,46]$.

The results of the clay mineral composition analysis are shown in Table 2. Based on the test results, the clay mineral contents in the Paleogene sandstones are relatively high, with an average of $17.11 \%$. The clay mineralogy of the Paleogene sandstones is dominated by $\mathrm{I}+\mathrm{I} / \mathrm{S}+\mathrm{C}$ types ( $\mathrm{I}=$ illite, $\mathrm{I} / \mathrm{S}=$ mixed-layer illite/smectite, $\mathrm{C}=$ chlorite) and characterized by very high illite content, high mixed-layer illite/smectite and chlorite contents, and lesser smectite and kaolinite contents (Figure 6). Among the samples, the highest illite content is $84 \%$, the lowest is $18 \%$, and the average is $51.6 \%$. For the second most dominant clay component, mixed-layer illite/smectite, the highest content is $60 \%$, the lowest is $2 \%$, and the average is $28.4 \%$; the average smectite content in the illite-smectite mixed layers is $13.7 \%$. The highest chlorite content is $56 \%$, the lowest is $2 \%$, and the average is $17.6 \%$. Smectite and kaolinite were observed in only a small number of samples.

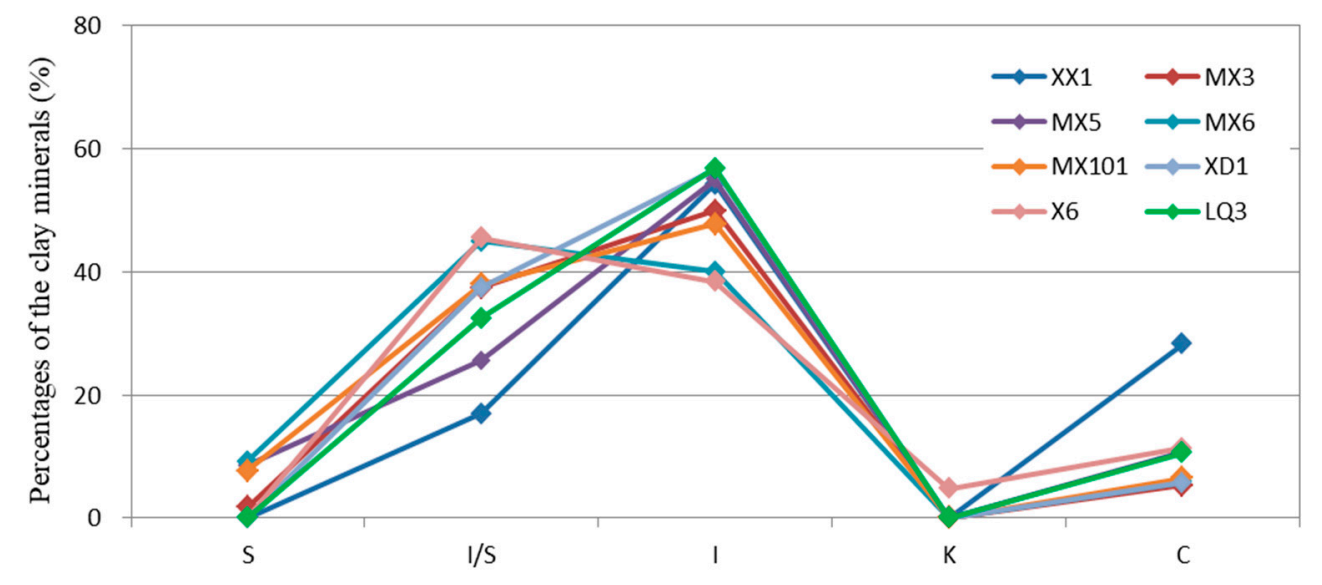

Figure 6. Average content of clay minerals in the Paleogene sandstones.

Illite is very well developed in the Paleogene sandstone samples, mostly in the form of filamentous, bridging, and curved leaf-like filling between particles and particle surfaces (Figure 7a,e,i). The mixed-layer illite/smectite is well developed and commonly seen on the surfaces of particles or filled between particles with semi-honeycomb or cotton flock shapes (Figure 7a-c,i).

Flaky chlorite is also common on the surfaces of the particles (Figure 7f). A small amount of smectite is distributed on the surfaces of the particles in honeycomb shapes as bridges between particles (Figure 7d,g,h). Kaolinite is only observed in the shallow layer of well MX101 and distributed with a book-like habit on the surfaces of the particles (Figure 7g). The illite contents in the lower Paleogene samples are substantially higher than those in the upper Paleogene samples, whereas the mixed-layer illite/smectite content decreases considerably from the upper to lower Paleogene (Figure 8), indicating that the clay minerals in the sandstone are mainly authigenic. The assemblage characteristics are the result of the joint action of sedimentary climate, sedimentary environment, and diagenetic environment. 
Table 2. X-ray diffraction results for Paleogene clay mineralogy.

\begin{tabular}{|c|c|c|c|c|c|c|c|c|c|c|c|c|c|c|c|c|c|}
\hline \multirow{2}{*}{ Well } & \multirow{2}{*}{$\begin{array}{l}\text { Buried } \\
\text { Depth } \\
\text { (m) }\end{array}$} & \multicolumn{5}{|c|}{$\begin{array}{c}\text { Relative Content of Clay } \\
\text { Minerals (\%) }\end{array}$} & \multirow{2}{*}{ 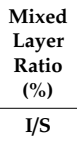 } & \multirow{2}{*}{$\begin{array}{c}\text { Total } \\
\text { Amount of } \\
\text { Clay }(\%)\end{array}$} & \multirow{2}{*}{ Well } & \multirow{2}{*}{$\begin{array}{l}\text { Buried } \\
\text { Depth } \\
(\mathrm{m})\end{array}$} & \multicolumn{5}{|c|}{$\begin{array}{l}\text { Relative Content of Clay } \\
\text { Minerals (\%) }\end{array}$} & \multirow{2}{*}{ 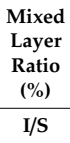 } & \multirow{2}{*}{$\begin{array}{c}\text { Total } \\
\text { Amoun } \\
\text { of Clay } \\
(\%)\end{array}$} \\
\hline & & $\mathrm{s}$ & $\mathrm{I} / \mathrm{S}$ & I & K & C & & & & & S & $\mathrm{I} / \mathrm{S}$ & I & K & C & & \\
\hline \multirow{38}{*}{ XX1 } & 4111.51 & 0 & 32 & 44 & 0 & 24 & 6 & 12.6 & \multirow{5}{*}{ MX3 } & 1236.04 & 5 & 43 & 49 & 0 & 3 & 7 & 11.8 \\
\hline & 4111.75 & 0 & 19 & 47 & 0 & 34 & 10 & 9.9 & & 1237.10 & 0 & 34 & 62 & 0 & 4 & 14 & 14.5 \\
\hline & 4112.11 & 0 & 11 & 72 & 0 & 17 & 12 & 21.3 & & 1237.70 & 4 & 49 & 44 & 0 & 3 & 5 & 15.8 \\
\hline & 4112.64 & 0 & 26 & 54 & 0 & 20 & 5 & 12.1 & & 1240.90 & 0 & 33 & 62 & 0 & 5 & 5 & 19.4 \\
\hline & 4112.99 & 0 & 7 & 80 & 0 & 13 & 9 & 22.4 & & 1241.34 & 5 & 32 & 58 & 0 & 5 & 5 & 17 \\
\hline & 4113.65 & 0 & 15 & 69 & 0 & 16 & 10 & 16 & \multirow{5}{*}{ MX5 } & 1932.67 & 0 & 18 & 66 & 0 & 16 & 11 & 10.9 \\
\hline & 4114.16 & 0 & 30 & 61 & 0 & 9 & 10 & 18.1 & & 1938.09 & 0 & 25 & 67 & 0 & 8 & 7 & 5.6 \\
\hline & 4114.82 & 0 & 32 & 42 & 0 & 26 & 12 & 21.8 & & 2284.59 & 12 & 34 & 40 & 0 & 14 & 37 & 16.3 \\
\hline & 4115.27 & 0 & 25 & 58 & 0 & 17 & 8 & 12.7 & & 2287.44 & 26 & 27 & 41 & 0 & 6 & 16 & 10.9 \\
\hline & 4115.60 & 0 & 22 & 51 & 0 & 27 & 5 & 10.8 & & 2290.20 & 5 & 24 & 61 & 0 & 10 & 5 & 21.3 \\
\hline & 4115.72 & 0 & 11 & 62 & 0 & 27 & 7 & 15.4 & \multirow{6}{*}{ MX6 } & 2324.36 & 29 & 34 & 31 & 0 & 6 & 10 & 14.1 \\
\hline & 4116.04 & 0 & 51 & 31 & 0 & 18 & 14 & 13.3 & & 2324.53 & 26 & 23 & 45 & 0 & 6 & 6 & 21.7 \\
\hline & 4116.34 & 0 & 38 & 41 & 0 & 21 & 15 & 12.3 & & 2325.48 & 0 & 49 & 41 & 0 & 10 & 5 & 27.7 \\
\hline & 4207.72 & 0 & 10 & 40 & 0 & 50 & 10 & 6.9 & & 2326.30 & 0 & 60 & 36 & 0 & 4 & 8 & 25.4 \\
\hline & 4208.32 & 0 & 9 & 35 & 0 & 56 & 8 & 6.6 & & 2326.46 & 0 & 48 & 45 & 0 & 7 & 6 & 25 \\
\hline & 4209.04 & 0 & 5 & 55 & 0 & 40 & 8 & 18.5 & & 2326.62 & 0 & 56 & 42 & 0 & 2 & 7 & 19.4 \\
\hline & 4209.52 & 0 & 18 & 36 & 0 & 46 & 21 & 10.7 & \multirow{6}{*}{ MX101 } & 1105.90 & 0 & 49 & 44 & 0 & 7 & 7 & 28.2 \\
\hline & 4210.43 & 0 & 26 & 22 & 0 & 52 & 8 & 10.7 & & 1106.34 & 8 & 34 & 52 & 0 & 6 & 5 & 21.3 \\
\hline & 4210.97 & 0 & 13 & 39 & 0 & 48 & 14 & 6.6 & & 1106.40 & 5 & 37 & 51 & 0 & 7 & 7 & 12.2 \\
\hline & 4211.18 & 0 & 9 & 37 & 0 & 54 & 8 & 15 & & 1106.45 & 16 & 22 & 55 & 0 & 7 & 25 & 14.1 \\
\hline & 4211.82 & 0 & 20 & 46 & 0 & 34 & 8 & 29.9 & & 1106.76 & 17 & 31 & 46 & 0 & 6 & 6 & 17.2 \\
\hline & 4212.32 & 0 & 29 & 18 & 0 & 53 & 9 & 24.5 & & 1107.38 & 0 & 55 & 39 & 0 & 6 & 5 & 15.1 \\
\hline & 4212.93 & 0 & 17 & 35 & 0 & 48 & 12 & 11.9 & \multirow{4}{*}{ XD1 } & 2997.40 & 0 & 39 & 55 & 0 & 6 & 9 & 9.7 \\
\hline & 4213.57 & 0 & 23 & 19 & 0 & 58 & 5 & 8.2 & & 2998.98 & 0 & 39 & 55 & 0 & 6 & 8 & 20.3 \\
\hline & 4214.61 & 0 & 23 & 30 & 0 & 47 & 8 & 8.3 & & 3001.3 & 0 & 39 & 56 & 0 & 5 & 5 & 11.1 \\
\hline & 4215.68 & 0 & 17 & 58 & 0 & 25 & 9 & 32.6 & & 3004.68 & 0 & 33 & 61 & 0 & 6 & 7 & 19.5 \\
\hline & 4847.08 & 0 & 9 & 84 & 0 & 7 & 11 & 42.5 & \multirow{8}{*}{ X6 } & 2846.58 & 0 & 48 & 37 & 0 & 15 & 55 & 11.3 \\
\hline & 4849.23 & 0 & 5 & 72 & 0 & 23 & 12 & 6.6 & & 2852.85 & 0 & 50 & 36 & 9 & 5 & 55 & 15.4 \\
\hline & 4850.46 & 0 & 4 & 78 & 0 & 18 & 13 & 15.9 & & 2854.88 & 0 & 39 & 39 & 9 & 13 & 60 & 10.1 \\
\hline & 4851.00 & 0 & 16 & 73 & 0 & 11 & 9 & 7.4 & & 2883.06 & 0 & 41 & 37 & 13 & 9 & 50 & 35.6 \\
\hline & 4851.39 & 0 & 24 & 53 & 0 & 23 & 7 & 10.7 & & 2936.99 & 0 & 41 & 45 & 0 & 14 & 40 & 63.4 \\
\hline & 4851.68 & 0 & 4 & 64 & 0 & 32 & 10 & 7.7 & & 2939.25 & 0 & 45 & 39 & 0 & 16 & 60 & 19.7 \\
\hline & 4852.40 & 0 & 18 & 69 & 0 & 13 & 13 & 9.2 & & 2943.15 & 0 & 53 & 34 & 7 & 6 & 55 & 14.2 \\
\hline & 4853.37 & 0 & 2 & 80 & 0 & 18 & 10 & 4.1 & & 2945.18 & 0 & 47 & 40 & 0 & 13 & 55 & 21.7 \\
\hline & 4853.91 & 0 & 3 & 79 & 0 & 18 & 11 & 13 & \multirow{6}{*}{ LQ3 } & 2165.25 & 0 & 37 & 54 & 0 & 9 & 6 & 17 \\
\hline & 4854.38 & 0 & 11 & 82 & 0 & 7 & 10 & 16.6 & & 2166.27 & 0 & 39 & 47 & 0 & 14 & 7 & 14.8 \\
\hline & 4854.62 & 0 & 19 & 69 & 0 & 12 & 14 & 15.2 & & 2167.48 & 0 & 29 & 62 & 0 & 9 & 9 & 46.5 \\
\hline & 4855.30 & 0 & 11 & 76 & 0 & 13 & 5 & 15.9 & & 2903.79 & 0 & 31 & 56 & 0 & 13 & 6 & 14.7 \\
\hline \multirow{3}{*}{ MX3 } & 1025.10 & 0 & 39 & 54 & 0 & 7 & 8 & 14.5 & & 2904.28 & 0 & 33 & 57 & 0 & 10 & 5 & 20.7 \\
\hline & 1031.05 & 0 & 32 & 61 & 0 & 7 & 9 & 9.9 & & 2905.88 & 0 & 26 & 65 & 0 & 9 & 6 & 44.7 \\
\hline & 1031.93 & 0 & 38 & 53 & 0 & 9 & 9 & 12.1 & $\mathrm{Av}$ & age & 2.0 & 28.4 & 51.6 & 0.5 & 17.6 & 13.7 & 17.1 \\
\hline
\end{tabular}

Standard: SY/T 5163-2010. The reason that $\mathrm{S}+\mathrm{I} / \mathrm{S}+\mathrm{I}+\mathrm{K}+\mathrm{C}=101$ or 99 is rounded numbers rather than data bias. $\mathrm{S}$ is smectite, $\mathrm{I} / \mathrm{S}$ is mixed-layer illite/smectite, $\mathrm{I}$ is illite, $\mathrm{K}$ is kaolinite, and $\mathrm{C}$ is chlorite. The mixed layer ratio (e.g., 20\%) indicates that the smectite content in the mixed-layer illite/smectite is $20 \%$. According to the relevant standards, I/S with a mixed layer ratio greater than $70 \%$ is classified as smectite.

The climatic characteristics are determined to be arid to semi-arid because the Paleogene parent rocks in the Qaidam Basin were mainly weathered through shallow physical weathering and supplemented by chemical weathering [47]. According to previous studies, inland saline lakes are conducive to the transformation of kaolinite and smectite to illite and the preservation of illite [39,47-49]. The average illite content in the Paleogene sandstone samples from the hinterland of the northern margin of the Qaidam Basin is $51.86 \%$, the average content of mixed-layer illite/smectite is $28.15 \%$, and thus the cumulative content of these two components is more than $80 \%$. Most of the samples do not contain smectite and kaolinite, which reflects the fact that the belly of the northern margin of the Qaidam Basin was dominated by a closed salinized lake basin in the Paleogene, and that the climate gradually became cold and dry. In an alkaline environment rich in $\mathrm{K}^{+}$, large amounts of 
kaolinite and smectite gradually transform into mixed-layer illite/smectite and illite. The average content of authigenic chlorite in the samples is $17.33 \%$, indicating that the diagenetic environment in the Paleogene was dominated by an alkaline environment rich in $\mathrm{Mg}^{2+}$, and that leaching and chemical weathering were weak. Longitudinally, with the increase of burial depth, the illite content increases, whereas the mixed-layer illite/smectite content decreases, indicating that with the increase of ground temperature, the transformation of mixed-layer illite/smectite to illite, and chlorite precipitation were accelerated. Therefore, it can be inferred that the hinterland of the northern margin of the Qaidam Basin in the Paleogene mainly developed closed saline lake basin deposits, and that the overall climatic environment was arid to semi-arid. The diagenetic environment was mainly an alkaline environment rich in $\mathrm{K}^{+}$and $\mathrm{Mg}^{2+}$, and leaching and chemical weathering were weak.
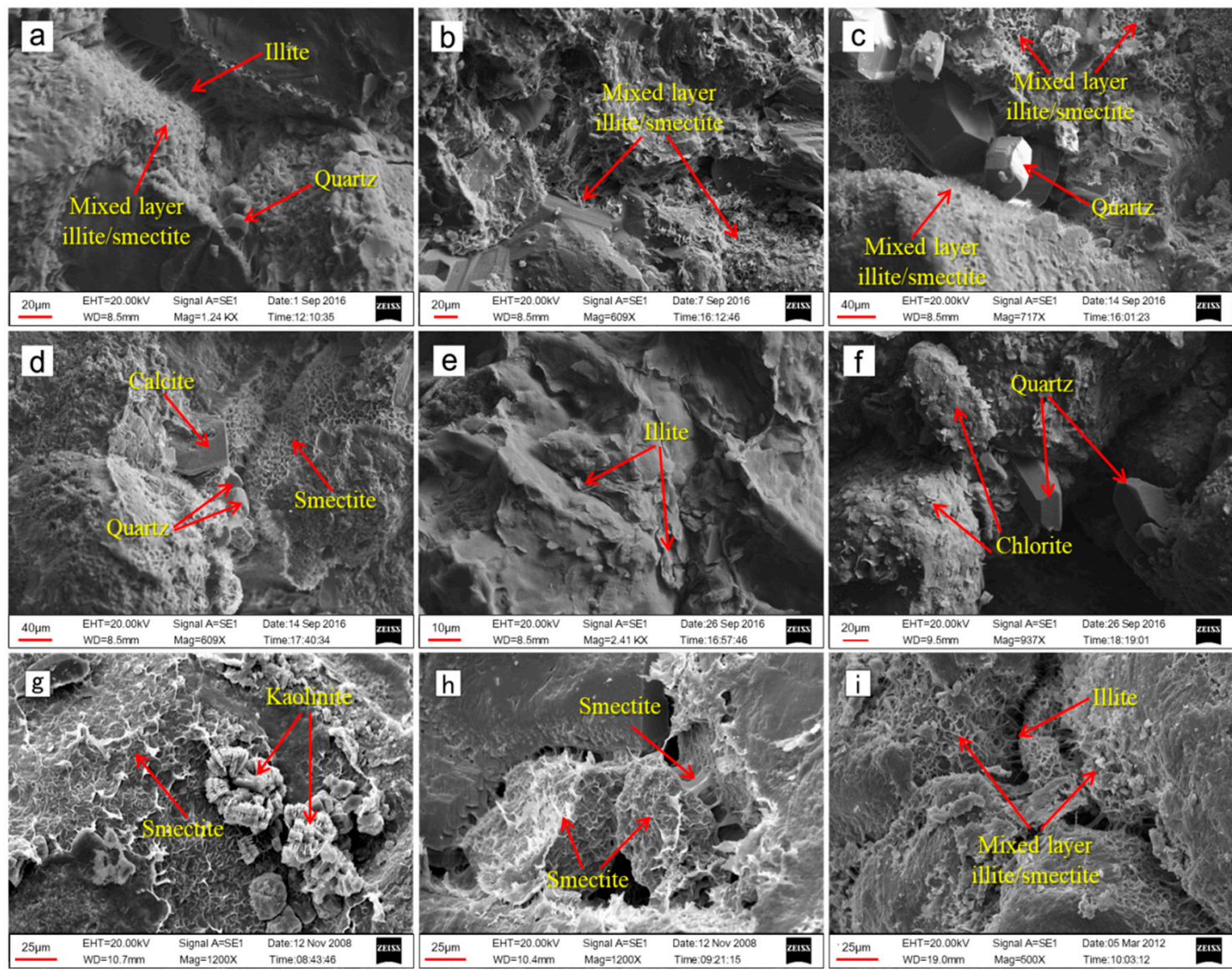

Figure 7. Scanning electron micrographs of the Paleogene sandstones. (a) XX1, $4111.51 \mathrm{~m}$, Figure 1. $4115.37 \mathrm{~m}$, mixed-layer illite/smectite filled between particles and particles surfaces; (c) XX1, $4209.77 \mathrm{~m}$, interstitial calcite, authigenic and enlarged quartz. Particle surfaces developed mixed-layer illite/smectite; (d) XX1, $4122.14 \mathrm{~m}$, interstitial calcite. Particle surfaces developed mixed-layer illite/smectite; (e) XX1, $4850.00 \mathrm{~m}$, curved leaf-like illite clay completely filled in intergranular pores; (f) XX1, $4853.05 \mathrm{~m}$, intergranular pores are developed with authigenic and enlarged quartz. Chlorite is developed on the particle surfaces; (g) MX101, $830.7 \mathrm{~m}$, Particle surfaces developed kaolinite and smectite; (h) MX101, $831.42 \mathrm{~m}$, a small amount of smectite bridges the surfaces of the particles in honeycomb form or those distributed between the particles; (i) MX5, $2389.90 \mathrm{~m}$, filamentous illite and mixed-layer illite/smectite filled between particles and particle surfaces. 

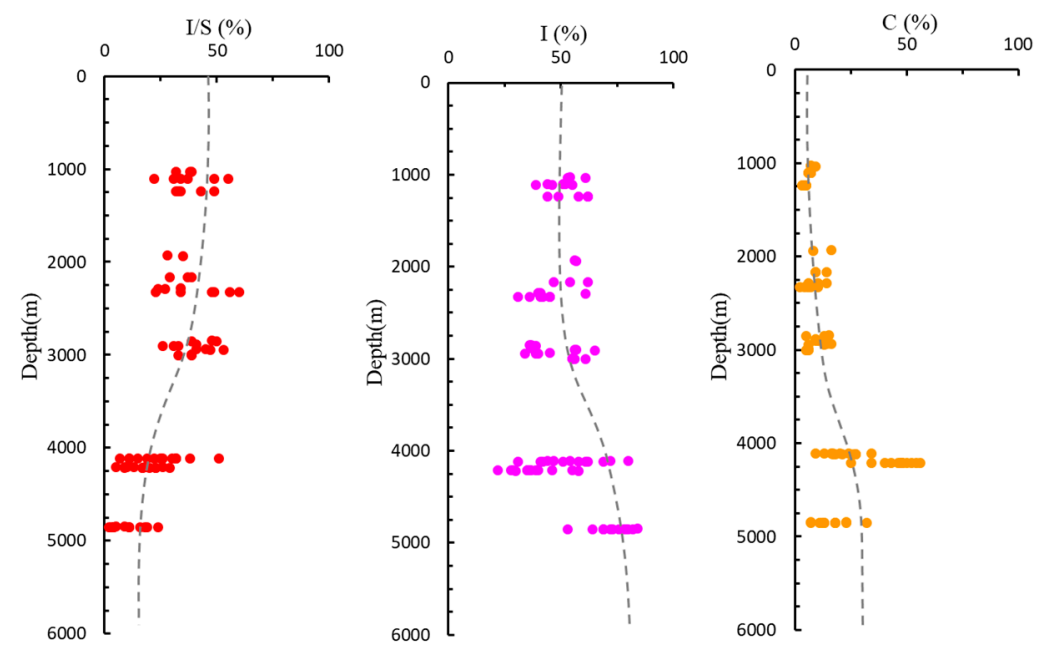

Figure 8. Longitudinal variation of relative contents of clay minerals. I/S = mixed-layer illite/smectite; $\mathrm{I}=$ illite; $\mathrm{C}=$ chlorite.

\section{Geochemical Features}

\subsection{Stable Carbon and Oxygen Isotopes}

The formation of carbonate cementation and carbon and oxygen isotope contents are closely related to the salinity and temperature of the sedimentary environment. Previous studies concluded that the increase of fluid salinity in a sedimentary environment will lead to a simultaneous increase of $\delta^{13} \mathrm{C}$ and $\delta^{18} \mathrm{O}$, whereas under a certain salinity, increased temperature will lead to lower $\delta^{18} \mathrm{O}$ [50]. Shackleton [51] calculated an empirical formula for paleotemperature based on oxygen isotopes: $\mathrm{T}=16.9-4.38(\delta \mathrm{c}-\delta \mathrm{w})+0.1(\delta \mathrm{c}-\delta \mathrm{w})^{2}$, where $\delta \mathrm{c}$ is the $\delta^{18} \mathrm{O}$ value of the measured sample (relative to the Pee Dee Belemnite standard) and $\delta \mathrm{w}$ is the ${ }^{18} \mathrm{O}$ value of sea water at that time (Standard Mean Ocean Water standard), which is 0 in this study [30]. The results (see Supplementary Materials Table S1) show that the formation temperature of the cement was between 68.2 and $107.7^{\circ} \mathrm{C}$ (Figure 9a). As a result of deep burial in the Lenghu seventh area, the diagenesis temperature was significantly higher than that in the northern part of the Mabei area. Keith et al. [52] summarized the relationship between $\delta^{13} \mathrm{C}$ and $\delta^{18} \mathrm{O}$, proposed an empirical isotopic coefficient, the paleosalinity value $Z\left[Z=2.048 \times\left(\delta^{13} \mathrm{C}+50\right)+\right.$ $\left.0.498 \times\left(\delta^{18} \mathrm{O}+50\right)\right]$, which can be used to distinguish marine limestone from freshwater limestone, and evaluated the formation environment of the cement [53]. The $\delta^{13} \mathrm{C}$ and $\delta^{18} \mathrm{O}$ values in the formula are relative to the PDB standard; when $Z>120$, the diagenesis fluid of carbonate cementation is mainly brackish water, and when $Z<120$, the diagenesis fluid is mainly fresh water. The calculation results show that the $Z$ value in the study area is between 104.2 and 115.6 (Figure 9a). Thus, the ancient salinity of the diagenesis fluid in the Lenghu seventh area and Mabei area was the same: mainly fresh water. Using the $\delta^{13} \mathrm{C}-\delta^{18} \mathrm{O}$ binary diagram model $[53,54]$ to analyze the carbon source of carbonate cementation in the Xiaganchaigou Formation in the center of the northern Qaidam Basin (Figure 9b), most of the carbonate cementation in the formation was determined to have occurred at a medium temperature and low salinity. In the Mabei area, because of the shallow burial and low formation temperature, the carbonate cement formed mainly in the late stage of early diagenesis. The carbonate cement is divided into two parts: a smaller part that formed in the diagenesis process before organic acid entered the rock layer and a larger part that formed by fluid precipitation after organic acids entered the rock. In the Lenghu seventh area, the burial depth was deep, the formation temperature was high, and the diagenetic stage was mainly in the early stage of middle diagenesis, with the diagenesis fluid mainly produced by the evolution of organic matter. 

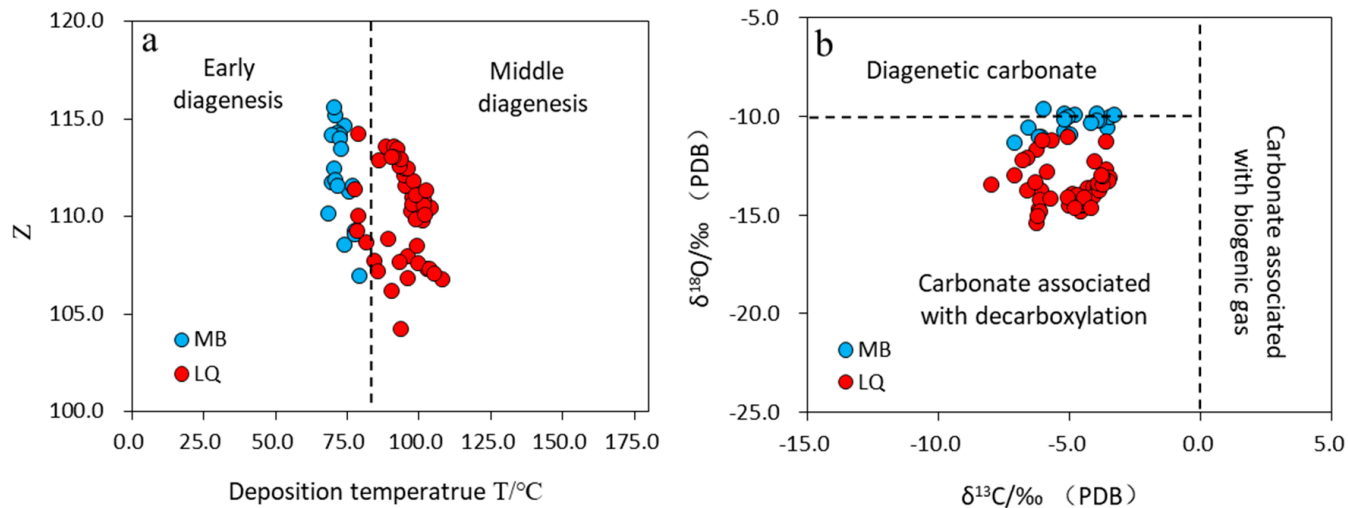

Figure 9. Characteristics of carbonate cementation in the Xiaganchaigou Formation in the center of the northern margin of the Qaidam Basin. (a) Covariation diagram of the paleosalinity value and paleotemperature; (b) covariation diagram of $\delta^{13} \mathrm{C}$ and $\delta^{18} \mathrm{O}$.

\subsection{Major Elements}

Weathering is an important characteristic of the provenance area, and the type and intensity of weathering affect not only the topography and geomorphology of the provenance area, but also the material supply in that area, which have an important impact on the material components of the sedimentary basin. The index used to determine the weathering degree of the source area, widely used at present, is the chemical index of alteration ( $\mathrm{CIA}=\mathrm{Al}_{2} \mathrm{O}_{3} /\left(\mathrm{Al}_{2} \mathrm{O}_{3}+\mathrm{CaO}+\mathrm{Na}_{2} \mathrm{O}+\mathrm{K}_{2} \mathrm{O}\right) \times 100$ ), where $\mathrm{CaO}^{*}$ represents $\mathrm{Ca}$ in silicate-bearing minerals only [55]. This index is used for shale and sandstone [56]. For instance, Bauluz [57] studied the source area of clastic rocks in the Precambrian-Paleozoic units of northwestern Spain, Rahman et al. [58] studied sandstone provenance in the Miocene Surma Group in Bangladesh, and Li et al. [59] studied the source area of Upper Carboniferous detrital rocks in the middle section of South Tianshan using this index.

The A-CN-K system is suitable for investigating fresh rock compositions and analyzing their weathering trends because the upper crust is dominated by plagioclase- and K-feldspar-rich rocks $[60,61]$ and their weathering products, clay minerals [56].

According to a study by Fedo et al. [56], a CIA value between 50 and 60 represents a low degree of chemical weathering, a CIA value between 60 and 80 represents moderate chemical weathering, and a CIA value between 80 and 100 reflects intense chemical weathering. Nesbitt and Young [61] proposed that CIA $=50-65$ indicates incipient chemical weathering under cold and dry climatic conditions, $\mathrm{CIA}=65-85$ indicates intermediate chemical weathering under warm and humid conditions, and CIA $=85-100$ indicates extreme chemical weathering under hot and humid conditions.

Pervasive K-metasomatism and metamorphism have affected the bulk composition of all samples, which caused $\mathrm{K}$ enrichment and required correction [56,62]. $\mathrm{K}_{2} \mathrm{O}$ addition to each weathered sample can alternatively be calculated according to [62]:

$$
\mathrm{K}_{2} \mathrm{O}_{\text {corr }}=\mathrm{m} \cdot \mathrm{A}+\mathrm{m} \cdot\left(\mathrm{C}^{*}+\mathrm{N}\right) /(1-\mathrm{m})
$$

where $\mathrm{m}=\mathrm{K} /\left(\mathrm{A}+\mathrm{C}^{*}+\mathrm{N}+\mathrm{K}\right)$ for the parent (protolith) sample; $\mathrm{A},\left(\mathrm{C}^{*}+\mathrm{N}\right)$, and $\mathrm{K}$ are molar values of $\mathrm{Al}_{2} \mathrm{O}_{3},\left(\mathrm{CaO}^{*}+\mathrm{Na}_{2} \mathrm{O}\right)$, and $\mathrm{K}_{2} \mathrm{O}$, respectively, and $\mathrm{CaO}^{*}$ indicates that $\mathrm{CaO}$ has been corrected [63] The chemical compositions (see Supplementary Materials Table S1) of the Xiaganchaigou Formation in the research area are plotted as molar proportions in the $\mathrm{A}-\mathrm{CN}-\mathrm{K}$ ternary diagram, where $\mathrm{CaO}^{*}$ represents $\mathrm{Ca}$ in silicate-bearing minerals only (Figure 10). The corrected CIA values are 56.3-75.7 with an average value of 66.5. The sample points plot close to the weathering trend line, which indicates that the source of the Paleogene sediment mainly formed under cold and dry climatic conditions and experienced limited chemical weathering; a smaller amount underwent intermediate chemical weathering under warm and humid conditions. 


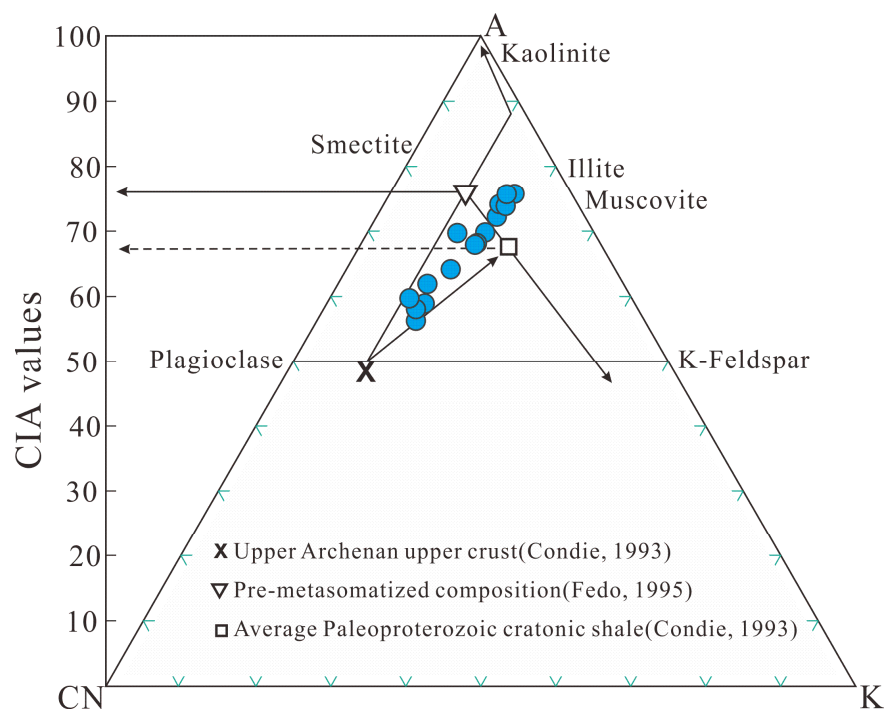

Figure 10. A-CN-K ternary diagram for samples of the Xiaganchaigou Formation in the center of the northern margin of the Qaidam Basin $[56,62,64]$.

\subsection{Trace Elements}

Source area analysis is based on the distribution of different trace elements in different rock combinations [65]. Inactive elements in clastic rocks (such as rare earth elements (REEs), La, Th, and Hf) are insoluble, stable, and unaffected by weathering and diagenesis. During diagenesis, these components are consistent and can enter the sedimentary rock almost equally from the source area. Therefore, they are widely used to reflect the attributes and geologic setting of detrital rock source areas [66]. According to the contents and ratios of trace elements in the sandstone of the Xiaganchaigou Formation (see Supplementary Materials Table S1), compared with the source areas of different tectonic backgrounds (Table 3), the Th and $\mathrm{Hf}$ trace element contents and $\mathrm{Rb} / \mathrm{Sr}$ and $\mathrm{Th} / \mathrm{U}$ ratios are closest to those of a continental island arc environment; the $U$ content is between continental island arc and active continental margin values; and the $\mathrm{La} / \mathrm{Y}, \mathrm{La} / \mathrm{Sc}$, and $\mathrm{Th} / \mathrm{Sc}$ ratios are also between continental island arc and active continental margin values. The results of the REE analysis (Table 4) show chondrite data from Boynton [67]. The average La content is $19.7 \times 10^{-6}$, the average Ce content is $35.6 \times 10^{-6}$, and the average $\sum R E E$ is $88.5 \times 10^{-6}$ with a higher $\mathrm{Eu} / \mathrm{Eu}^{*}$ value and an average of 0.75 . A comparison of these data with the characteristics of REEs with different tectonic backgrounds indicates that the values of $\mathrm{La}, \mathrm{Ce}, \sum \mathrm{REE}$, and $\mathrm{Eu} / \mathrm{Eu}^{*}$ are all close to the values for a continental island arc, whereas the values of $\mathrm{La} / \mathrm{Yb}, \mathrm{LaN} / \mathrm{YbN}$, and $\sum \mathrm{LREE}$ (light rare earth elements)/ $\sum \mathrm{HREE}$ (heavy rare earth elements) are between the continental island arc and active continental margin values.

The ratio of compatible and incompatible elements can be used to distinguish whether the primary rocks were felsic or mafic, such as the Th/Sc ratio, which is an indicator of chemical differentiation of igneous rocks because Th and Sc are incompatible and compatible in igneous rock systems, respectively [56]. The $\mathrm{Zr} / \mathrm{Sc}$ ratio is a useful indicator of zircon enrichment because $\mathrm{Zr}$ strongly concentrates in zircon, whereas Sc usually preserves the characteristics of the provenance area $[66,69]$. Typically, it is difficult to distinguish between an island arc source and recycled continental crust source for sedimentary rocks simply based on chemical characteristics because the chemical composition of the continental crust shows characteristics similar to those of an island arc [70]. Bhatia [71], Bhatia and Crook [68], and Floyd et al. [72] suggested that the tectonic background can be judged based on the geochemical composition of sandstone (Figure 5), and a series of diagrams have been proposed to identify different tectonic environments, such as ocean island arc, continental island arc, active continental margin, and passive continental margin settings. Although questions remain regarding this approach [73], it has achieved great success and has been widely applied [74-78]. 
Table 3. Comparison of detrital rocks of the Xiaganchaigou Formation with the trace element characteristics of sandstones under various tectonic settings (revised from Bhatia and Crook [68] and Li et al. [59].

\begin{tabular}{cccccc}
\hline $\begin{array}{c}\text { Tectonic } \\
\text { Setting }\end{array}$ & $\begin{array}{c}\text { Oceanic } \\
\text { Island Arc }\end{array}$ & $\begin{array}{c}\text { Continental } \\
\text { Island Arc }\end{array}$ & $\begin{array}{c}\text { Active } \\
\text { Continental Margin }\end{array}$ & $\begin{array}{c}\text { Passive } \\
\text { Margins }\end{array}$ & XX1 $(\boldsymbol{n}=\mathbf{3 4})$ \\
\hline $\mathrm{Th}\left(\times 10^{-6}\right)$ & $2.27 \pm 0.7$ & $11.1 \pm 1.1$ & $18.8 \pm 3.0$ & $16.7 \pm 3.5$ & $5.69(2.20-13.15)$ \\
$\mathrm{U}\left(\times 10^{-6}\right)$ & $1.09 \pm 0.21$ & $2.53 \pm 0.24$ & $3.90 \pm 0.5$ & $3.20 \pm 0.8$ & $2.99(0.79-10.75)$ \\
$\mathrm{Hf}\left(\times 10^{-6}\right)$ & $2.1 \pm 0.6$ & $6.3 \pm 2.0$ & 6.8 & 10.1 & $3.62(1.61-8.85)$ \\
$\mathrm{Rb} / \mathrm{Sr}$ & $0.05 \pm 0.05$ & $0.65 \pm 0.33$ & $0.89 \pm 0.24$ & $1.19 \pm 0.4$ & $0.60(0.03-1.170$ \\
$\mathrm{Th} / \mathrm{U}$ & $2.1 \pm 0.78$ & $4.6 \pm 0.45$ & $4.8 \pm 0.38$ & $5.6 \pm 0.7$ & $2.72(1.22-5.27)$ \\
$\mathrm{La} / \mathrm{Y}$ & $0.48 \pm 0.12$ & $1.02 \pm 0.07$ & $1.33 \pm 0.09$ & $1.31 \pm 0.26$ & $1.40(0.90-1.83)$ \\
$\mathrm{La} / \mathrm{Sc}$ & $0.55 \pm 0.22$ & $7.82 \pm 0.3$ & $4.55 \pm 0.8$ & $6.25 \pm 1.35$ & $4.20(2.39-6.70)$ \\
$\mathrm{Th} / \mathrm{Sc}$ & $0.15 \pm 0.13$ & $0.85 \pm 0.13$ & $2.59 \pm 0.5$ & $3.06 \pm 0.8$ & $1.75(0.48-4.76)$ \\
\hline
\end{tabular}

Table 4. Comparison of detrital rocks of the Xiaganchaigou Formation with the rare earth element characteristics of sandstones under various tectonic settings [68,79]. REE: rare earth elements.

\begin{tabular}{|c|c|c|c|c|c|c|c|c|}
\hline \multirow[b]{2}{*}{ Tectonic Settings } & \multirow[b]{2}{*}{ Provenance Type } & \multicolumn{7}{|c|}{ REE } \\
\hline & & $\begin{array}{c}\text { La } \\
\left(\times 10^{-6}\right)\end{array}$ & $\begin{array}{c}\mathrm{Ce} \\
\left(\times 10^{-6}\right)\end{array}$ & $\begin{array}{c}\sum \mathrm{REE} \\
\left(\times 10^{-6}\right)\end{array}$ & $\mathrm{La} / \mathrm{Yb}$ & $\mathrm{La}_{\mathbf{N}} / \mathrm{Yb}_{\mathrm{N}}$ & $\begin{array}{c}\sum \text { LREE } \\
/ \sum \text { HREE }\end{array}$ & $\mathrm{Eu} / \mathrm{Eu}^{*}$ \\
\hline $\begin{array}{l}\text { Oceanic } \\
\text { island arc }\end{array}$ & $\begin{array}{l}\text { Undissected } \\
\text { Magmatic arc }\end{array}$ & $8 \pm 1.7$ & $19 \pm 3.7$ & $58 \pm 10$ & $4.2 \pm 1.3$ & $2.8 \pm 0.9$ & $3.8 \pm 0.9$ & $1.04 \pm 0.11$ \\
\hline $\begin{array}{l}\text { Continental } \\
\text { island arc }\end{array}$ & $\begin{array}{c}\text { Dissected } \\
\text { magmatic arc }\end{array}$ & $27 \pm 4.5$ & $59 \pm 8.2$ & $146 \pm 20$ & $11.0 \pm 3.6$ & $7.5 \pm 2.5$ & $7.7 \pm 1.7$ & $0.79 \pm 0.13$ \\
\hline $\begin{array}{l}\text { Andean-type } \\
\text { continental } \\
\text { margin }\end{array}$ & $\begin{array}{c}\text { Uplifted } \\
\text { basement }\end{array}$ & 37 & 78 & 186 & 12.5 & 8.5 & 9.1 & 0.60 \\
\hline $\begin{array}{l}\text { Passive } \\
\text { margins }\end{array}$ & $\begin{array}{l}\text { Craton interior } \\
\text { tectonic highlands }\end{array}$ & 39 & 85 & 210 & 15.9 & 10.8 & 8.5 & 0.56 \\
\hline$X X 1$ & 1 & 19.7 & 35.6 & 88.5 & 13.1 & 8.9 & 8.19 & 0.75 \\
\hline
\end{tabular}

For this study, the ratios of trace elements such as $\mathrm{La} / \mathrm{Th}$ and Hf (Figure 11) and Th-Co-Zr/10 ternary diagrams (Figure 12) were used to comprehensively evaluate the tectonic environment. The common conclusions of the two approaches are that the sandstone source for the Xiaganchaigou Formation is in a stable tectonic environment, and that the rock composition is similar to the upper crust or intermediate igneous rock, with only a small amount of basic rocks.

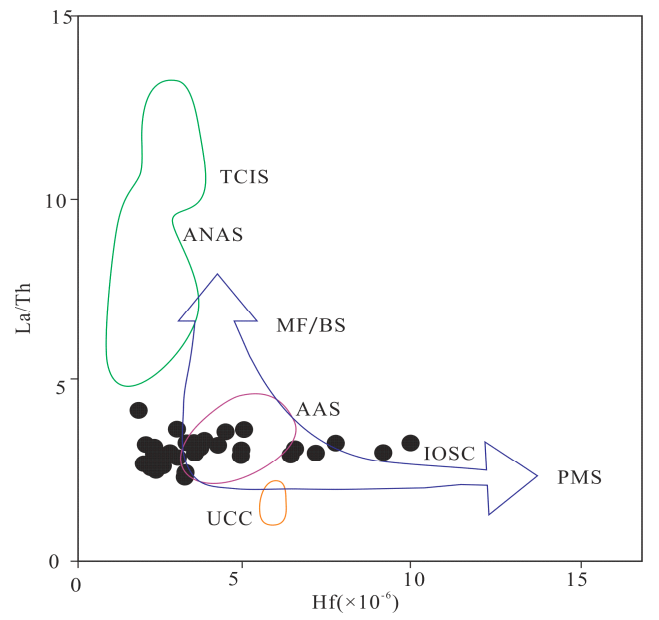

Figure 11. La/Th-Hf diagram of the Xiaganchaigou Formation (after Floyd et al. [72]). UCC—upper continental crust; PMS - passive margin source; AAS-acidic arc source; IOSC-increasing old sediment; MF/BS—mixed felsic/intermediate source; ANAS—andesitic arc source; TCIS—-tholeiitic ocean island source. 


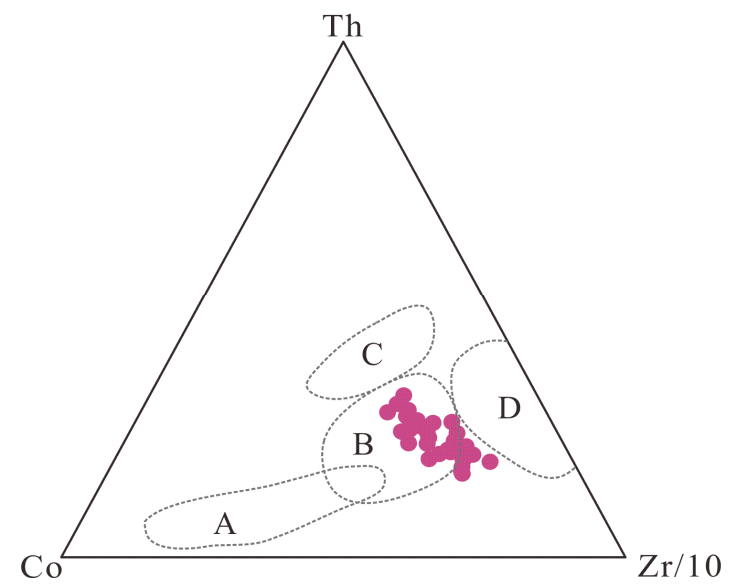

Figure 12. Trace element discriminant diagrams of the Xiaganchaigou Formation (after Bhatia and Crook [68]). A-oceanic island arc; B-continental island arc; C-active continental margin; $\mathrm{D}$-passive margin.

\subsection{Rare Earth Elements}

The results of REE analysis of the XX1 well core are shown in Table 4 and Table S1). The total content of REEs is moderate, ranging from $80.62 \times 10^{-6}$ to $180.72 \times 10^{-6}$, with an average of $126.70 \times 10^{-6}$. The $\sum$ LREE is between $71.59 \times 10^{-6}$ and $162.32 \times 10^{-6}$ and the average is $113.86 \times 10^{-6}$. The $\sum$ HREE ranges from $8.68 \times 10^{-6}$ to $18.90 \times 10^{-6}$ with an average of $12.84 \times 10^{-6}$. The corresponding $\sum$ LREE/ $\sum$ HREE $=7.93-10.26$, with an average of 8.81 and $\delta$ Eu is between 0.60 and 0.74 . The REE contents shows apparent characteristics of LREE enrichment and negative Eu anomalies. Figure 13a shows that the standardized diagram characteristics of chondrites in the sandstone of the Xiaganchaigou Formation in XX1 are relatively close, and almost all are arranged in parallel. The results show that sandstone deposition in the Xiaganchaigou Formation in the XX1 well area came from the same source. The distribution curve is characterized by a right tilt of the " $\mathrm{V}$ " type, with an enrichment of LREEs (light rare earth elements) and depletion of HREEs (heavy rare earth elements). Except for the Eu valley, the curve is relatively smooth without visible fluctuation, which clearly indicates that both LREEs and HREEs underwent fractionation. Bhatia [79] suggested that the enrichment of LREEs with a clear negative Eu anomaly indicates characteristics of a more stable tectonic environment. Above all, these results indicate that the sediment source for the XX1 well area was mainly from the granite area of upper crust, which is a relatively stable tectonic environment. Based on a comparison of the above REE data with those of the surrounding mountains (Figure 13b-d), the distribution pattern of REEs in the XX1 well is consistent with that of REEs in Kowloon Mountain. Therefore, it can be considered that the sediment source of the Xiaganchaigou Formation in the XX1 well is mainly from the Kowloon Mountain area in the middle of the Qilian Mountains. 

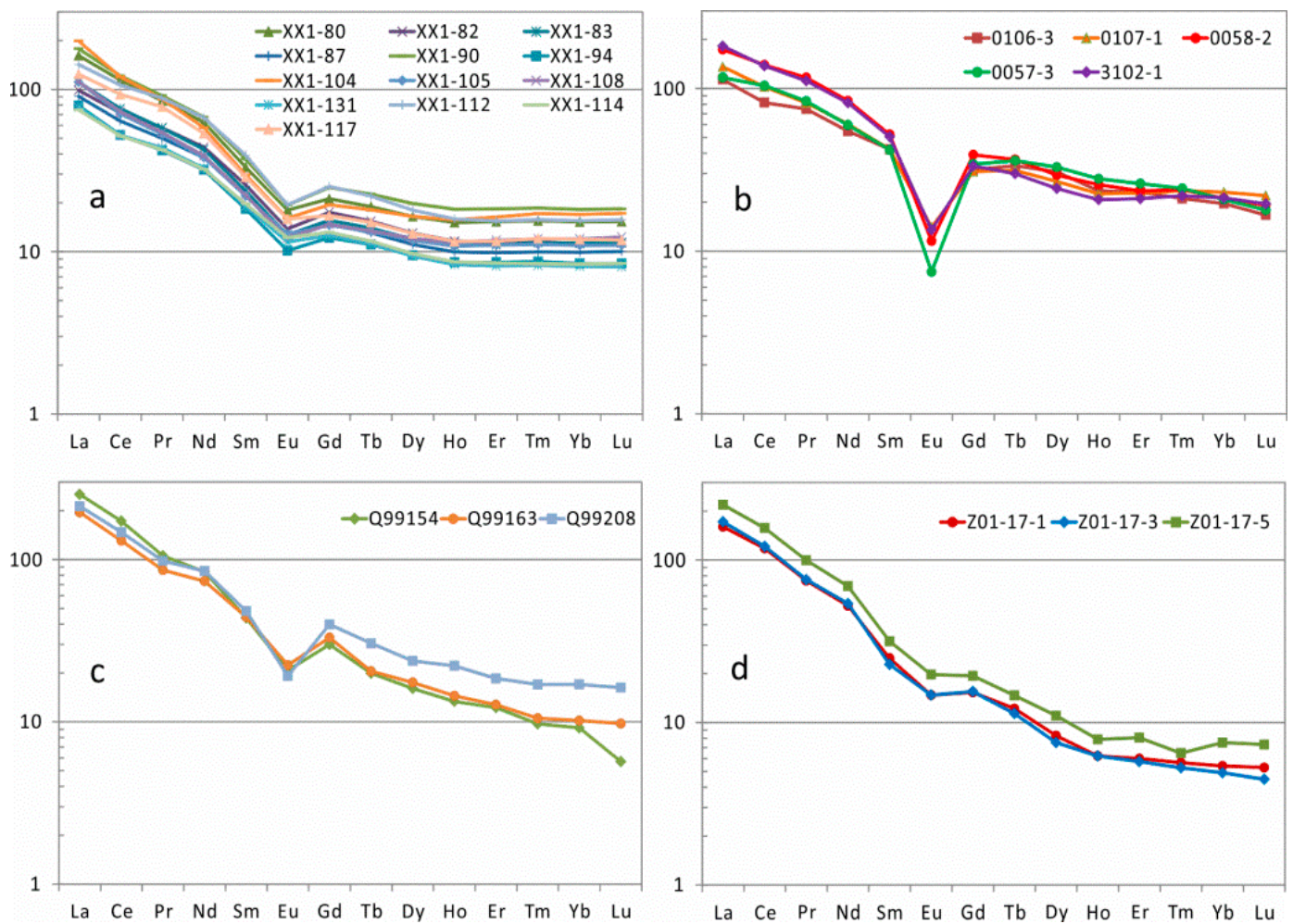

Figure 13. Chondrite-normalized REE patterns for samples of the northern Qaidam Basin (chondrite values from McDonough and Sun [80]). (a) Samples from the XX1 well clastic sedimentary rock; (b) granitic gneiss of the Altyn Tagh (Qin et al. [81]); (c) gneiss of Kowloon Mountain (Meng et al. [82]);

(d) gneiss of Xitie Mountain (Meng et al. [82]).

\section{Discussion and Conclusions}

Regardless of the complexity of the tectonic evolution prior to the Mesozoic, the subduction of oceanic crust and collision between continental lithospheric plates completed in northwestern China by the end of the Triassic [16]. The formation time and formation mode of the peripheral fault zone in the Qaidam Basin differ. The collision of the Kunlun fault zone was completed in the Permian, and the relatively lagging main orogenic uplift period ended by the end of the Middle Triassic [17,18]. During the Caledonian period, the Qilian fault zone was closed, uplifted, and orogenic [19,21]. Starting from the Triassic, the northwest region entered a stage of intracontinental evolution, and the major tectonic events were mainly affected by the evolution of the southern Tethys tectonic domain [22]. The Qilian Mountain orogenic belt also occurred in this large-scale tectonic background and experienced the process of a collision-suture-uplift orogeny. The results of facies analysis of the Paleogene clastic rocks in the center of the northern Qaidam Basin show that the tectonic background of the source area was mainly based on a recycled orogenic belt, magmatic island arc, collision suture, and fold-reverse fault zone, which indicates that the provenance of the center of the northern Qaidam Basin is mainly from the Qilian orogenic belt. Mixture source identification models indicate that the source of the Paleogene clastic rocks in the center of the northern Qaidam Basin is mainly quartz sediment and acidic igneous rocks with a small amount from neutral igneous rocks. The tectonic background was mainly an active continental magmatic arc, subduction accretion, or a fold-thrust belt. Through comparison of the rare earth element distribution model, it is found that the provenance area was in the region of the Yuka-Jiulong Mountains in the middle of the Qilian Mountains, which represents a moderate transportation distance.

Wedepohl [83] estimated that the mineral composition of the upper crust is about $21 \%$ quartz, $41 \%$ plagioclase, and $21 \%$ potassium feldspar (volume fraction). Feldspar is the most important 
parent-source mineral in the process of chemical weathering of the upper crust. $\mathrm{Na}, \mathrm{K}, \mathrm{Ca}$, and other alkali metal elements are largely lost with surface fluids in the form of ions, and clay minerals (e.g., smectite, illite, kaolinite) form. During this process, the molar fraction of $\mathrm{Al}_{2} \mathrm{O}_{3}$, the principal component of weathering products, varies with chemical weathering intensity. Accordingly, Nesbitt and Young [55] put forward the CIA as an indicator to reflect the weathering degree of the source region when they studied Paleoproterozoic clastic rocks from the Huronian of Canada (higher CIA values are associated with stronger weathering). In 1989, Nesbitt and Young suggested that CIA = 50-65 reflects incipient chemical weathering under cold and dry climatic conditions, CIA $=65-85$ reflects intermediate chemical weathering under warm and humid conditions, and CIA $=85-100$ reflects extreme chemical weathering in hot and humid conditions [61]. The upper crust (UCC) points to continental shale (PAAS) to represent the direction of continental weathering. The corrected CIA values are 56.3-75.7 with an average value of 66.5. Moreover, the sample points are close to the weathering trend line, indicating that the Paleogene provenance in the center of the northern Qaidam Basin mainly formed under cold and dry climatic conditions and experienced limited chemical weathering with a small amount subjected to moderate chemical weathering under warm and humid conditions. X-ray diffraction analysis of clay minerals shows that the illite content is relatively high followed by chlorite and mixed layers of illite and smectite, which reflects the climatic and environmental characteristics of arid and semi-arid areas. The characteristics of the carbon and oxygen isotopes reveal that the sedimentary environment in this period was dominated by freshwater deposition. Therefore, the sedimentary environment in the Paleozoic in the center of the northern Qaidam Basin is inferred to have been dominated by cold and dry freshwater deposition with moderate to weak weathering.

The investigation of source, sedimentary environment, and diagenetic environment of the sandstone reservoir in the lower part of the lower Ganchaigou Formation in the northern margin of Qaidam provides important information of the sedimentary system and evolution law of the reservoir rock, which provides a reference for further oil and gas exploration in this area.

Supplementary Materials: The following are available online at http://www.mdpi.com/2075-163X/10/6/505/s1, Table S1: Geochemical data of the Paleogene sandstones in the Center of the Northern Margin of the Qaidam Basin.

Author Contributions: Conceptualization, G.S., M.W., and J.G.; Methodology, G.S., M.W., and J.G.; Formal Analysis, G.S., Y.W., and M.W.; Investigation, G.S., Y.Y., and M.W.; Writing-Original Draft Preparation, G.S., M.W., J.G., Y.W., and Y.Y.; Writing-Review and Editing, G.S., M.W., J.G., Y.W., and Y.Y. All authors have read and agreed to the published version of the manuscript.

Funding: This work was financially supported by the CAS "Light of West China" Program (Y304RC1SGQ), the Nature Science Foundation of Gansu Province (Grant No. 1308RJZA310), and a Key Laboratory Project of Gansu Province (Grant No. 1309RTSA041).

Acknowledgments: We would like to thank Junli Qiu for technical assistance with chemical analyses.

Conflicts of Interest: The authors declare no conflict of interest.

\section{References}

1. Singer, A.M.C. Plate Tectonic Theory and Orogeny; Ding, X.; Zhou, Z.Y.; Zhao, G.X., Translators; Fudan University Publishing House: Shanghai, China, 1992; pp. 36-120.

2. Ge, X.H.; Ren, S.M.; Ma, L.X.; Wu, G.D.; Liu, Y.J.; Yuan, S.H. Multi-stage uplifts of the Qinghai-Tibet plateau and their environmental effects. Earth Sci. Front. 2006, 13, 118-130.

3. Zheng, D.; Yao, T.D. Uplifting of Tibetan Plateau with its environmental effects. Adv. Earth Sci. 2006, 21, 451-458.

4. Zheng, D.; Yao, T.D. Research progress on formation and evolution of Qinghai-Tibet Plateau and its environmental and resource effects. China Basic Sci. 2004, 6, 15-21.

5. Sun, G.Q.; Liu, W.M.; Guo, J.J.; Wang, Y.T. Fission-track evidence of tectonic evolution in the northwestern qaidam basin, china. J. Earth Syst. Sci. 2018, 127, 12. [CrossRef]

6. Zhai, G.M.; Xu, F.Y. A reconsideration of Qaidam Basin for a great breakthrough in oil and natural gas exploration. Acta Pet. Sin. 1997, 18, 1-7. 
7. Dai, J.S.; Ye, X.S.; Tang, L.J.; Jin, Z.J.; Shao, W.B.; Hu, Y.; Zhang, B.S. Tectonic units and oil-gas potential of the Qaidam Basin. Chin. J. Geol. 2003, 38, 291-296.

8. Fu, S.T.; Ma, D.D.; Chen, Y.; Zhang, G.Q.; Wu, K.Y. New advance of petroleum and gas exploration in Qaidam Basin. Acta Pet. Sin. 2016, 37 Suppl. S1,1-10.

9. Guo, J.; Sun, G.; Men, H.; Zhu, W.; Ma, J.; Zhu, J.; Guan, B.; Shi, J. Genetic analysis of anomalously high porosity zones in deeply buried reservoirs in the west part of northern edge of Qaidam Basin, NW China. Acta Sedimentol. Sin. 2018, 36, 777-786.

10. Singer, A. The paleoclimatic interpretation of clay minerals in soils and weathering profiles. Earth Sci. Rev. 1980, 15, 303-326. [CrossRef]

11. Chen, B.; Wang, F.; Shi, J.; Chen, F.; Shi, H. Origin and Sources of Minerals and Their Impact on the Hydrocarbon Reservoir Quality of the Paleogene Lulehe Formation in the Eboliang Area, Northern Qaidam Basin, China. Minerals 2019, 9, 436. [CrossRef]

12. Deconinck, J.F.; Blanc-Valleron, M.M.; Rouchy, J.M.; Camoin, G.; Badaut-Trauth, D. Palaeoenvironmental and diagenetic control of the mineralogy of Upper Cretaceous-Lower Tertiary deposits of the Central Palaeo-Andean basin of Bolivia (Potosi area). Sediment. Geogr. 2000, 132, 263-278. [CrossRef]

13. Li, Y.C.; Wang, S.M.; Huang, Y.S. The lake sediments rediments to environmental and climatic change. Adv. Earth Sci. 1999, 14, 412-416, (In Chinese with English abstract).

14. Fan, Y.H.; Qu, H.J.; Wang, H.; Yang, X.C.; Feng, Y.W. The application of trace elements analysis to identifying sedimentary media environment: A case study of Late Triassic strata in the middle part of western Ordos Basin. Geol. China 2012, 39, 382-389.

15. Yu, S.H.; Zheng, H.H. REE of sediments of the Chang Liushui section at Zhong Wei County of Ning Xia and the environmental significance. Acta Sedimentol. Sin. 1999, 17, 149-155. [CrossRef]

16. Zheng, J.J.; Su, L.; Liu, X.W.; Yang, X.; Sun, G.Q.; Zhang, S.C.; Liu, Y.H. The conversion of dynamical mechanisms and formation of intra-plate depression under the compress(-shear) dynamics. Geotecton. Metallog. 2009, 33, 107-114.

17. Zheng, J.; Peng, Z. Tectonic kinematic process of chief oil-gas bearing basins and the formation of oil-gas in China. Acta Sedimentol. Sin. 1995, 13, 160-168.

18. Deway, F.J. Extensional collapse of orogens. Teetonics 1988, 7, 1123-1139. [CrossRef]

19. Huang, R.H. Geotectonic evolution and its characteristics in Qilianshan region. Geotecton. Metallog. 1996, 20, 95-104.

20. Zhao, S.G. The features and tectonic evolution of the Qilian orogenic belt. Acta Geol. Gansu 1996, 5, 16-29.

21. Yang, J.S.; Xu, Z.Q.; Li, H.B.; Wu, C.L.; Cui, J.W.; Zhang, J.X.; Chen, W. Discovery of eclogite at northern margin of Qaidam basin, NW China. Chin. Sci. Bull. 1998, 43, 1755-1760. [CrossRef]

22. Sun, G.Q.; Zheng, J.J.; Su, L.; Liu, X.W.; Yang, X.; Liu, Y.H. Mesozoic-Cenozoic Tectonic Evolution in Northwestern Qaidam Basin. Nat. Gas Geosci. 2010, 21, 212-217.

23. Sun, G.Q.; Si, D.; Wang, M.; Shen, Y.S.; Zhou, F.; Hao, X.M.; Niu, F. The tectonic kinematic process and the types of oil and gas reservoirs in northern margin of Qaidam basin. Nat. Gas Geosci. 2012, 23, 826-832.

24. Sun, G.Q.; Du, Z.M.; Jia, Y.Y.; Zhou, F.; Hao, X.M.; Shi, J.A. Sedimentary model since Paleogene in northern margin of Qaidam Basin. Lithol. Reserv. 2012, 24, 13-18.

25. Jian, X.; Guan, P.; Zhang, D.W.; Zhang, W.; Feng, F.; Liu, R.J.; Lin, S.D. Provenance of Tertiary sandstone in the northern Qaidam basin, northeastern Tibetan Plateau: Integration of framework petrography, heavy mineral analysis and mineral chemistry. Sediment. Geol. 2013, 290, 109-125. [CrossRef]

26. Sun, Z.M.; Yang, Z.Y.; Pei, J.L.; Ge, X.H.; Wang, X.S.; Yang, T.S.; Li, W.M.; Yuan, S.H. Magnetostratigraphy of Paleogene sediments from northern Qaidam Basin, China: Implications for tectonic uplift and block rotation in northern Tibetan plateau. Earth Planet. Sci. Lett. 2005, 237, 635-646. [CrossRef]

27. Sun, Z.C.; Jing, M.C.; Sun, N.D.; Lu, Y.L.; Cao, L. Discussion on boundary between the upper and lower members of Xiaganchaigou Formation of Paleogene in Well Kun-2 Qaidam Basin. J. Palaeogeogr. 2007, 9, 611-618.

28. Wang, X.M.; Qiu, Z.D.; Li, Q.; Wang, B.Y.; Qiu, Z.X.; Downs, W.R.; Xie, G.P.; Xie, J.Y.; Deng, T.; Takeuchi, G.T.; et al. Vertebrate paleontology, biostratigraphy, geochronology, and paleoenvironment of Qaidam Basin in northern Tibetan Plateau. Palaeogeogr. Palaeoclimatol. Palaeoecol. 2007, 254, 363-385. [CrossRef]

29. Wang, Q.; Hao, L.W.; Chen, G.J.; Zhang, G.C.; Zhang, R.; Ma, X.F.; Wang, H. Forming mechanism of carbonate cements in siliciclastic sandstone of Zhuhai Formation in Baiyun sag. Acta Pet. Sin. 2010, 31, 553-558. 
30. Sun, G.Q.; Yin, J.G.; Zhang, S.C.; Lu, X.C.; Zhang, S.Y.; Shi, J.A. Diagenesis and sedimentary environment of Miocene series in Eboliang III area. Environ. Earth Sci. 2015, 74, 5169-7159. [CrossRef]

31. Dickinson, W.R. Interpreting Provenance Relations from Detrital Modes of Sandstones. In Provenance of Arenites; Zuffa, G.G., Ed.; NATO ASI Series (Series C: Mathematical and Physical Sciences); Springer: Dordrecht, The Netherland, 1985; Volume 148, pp. 333-361. [CrossRef]

32. Ingersoll, R.V.; Bullard, T.F.; Ford, R.L.; Grimm, J.P.; Pickle, J.D.; Sares, S.W. The effect of grain size on detrital modes: A test of the Gazzi-Dickinson point-counting method. J. Sediment. Petrol. 1984, 54, $103-116$. [CrossRef]

33. Long, H.; Wang, C.H.; Liu, Y.P.; Ma, H.Z. Application of clay minerals in paleoenviroment research. J. Salt Lake Res. 2007, 15, 21-25. [CrossRef]

34. Jin, N.; Li, A.C.; Liu, H.Z.; Meng, Q.Y.; Wan, S.M.; Xu, Z.K. Clay minerals in surface sediment of the northwest parece vela basin: Distribution and provenance. Oceanol. Limnol. Sin. 2007, 6, 504-511.

35. Fu, W.J. Influence of clay minerals onsandstone reservoir properties. J. Palaeogeogr. 2000, 3, 59-67.

36. Dong, W.H.; Su, X.S.; Hou, G.C.; Lin, X.Y.; Liu, F.T. Study on distribution law of TDS and main ion concentration in groundwater in the Ordos Cretaceous Artesian Basin. Hydrogeol. Eng. Geol. 2008, 4, 11-16.

37. Wu, B.H.; Yangm, H.N.; Li, S.J. The Mineral Composition of Sediment and Sedimentation of Central Pacific; Geological Publishing House: Beijing, China, 1993; pp. 44-45.

38. Tang, Y.J.; Jia, J.Y.; Xie, X.D. Environment significance of clay minerals. Earth Sci. Front. 2002, 2, 337-341.

39. Lu, C.X. Clay minerals as indicators of paleoenvironment. J. Desert Res. 1997, 4, 456-460.

40. Liu, Y. The clay mineral characteristics and the analysis for sedimentary environment of the Late Cretaceous in Songliao Basin. Acta Sedimentol. Sin. 1985, 4, 131-137.

41. Xie, Y.; Wang, J.; Li, L.X.; Xie, Z.W.; Deng, G.H.; Li, M.H.; Jiang, X.S. Distribution of the Cretaceous clay minerals in Ordos basin, China and its implication to sedimentary and diagenetic environment. Geol. Bull. China 2010, 29, 93-104. [CrossRef]

42. Yuan, H.R.; Nie, Z.; Liu, J.Y.; Wang, M. Paleogene sedimentary characteristics and their paleoclimatic implications in the Baise Basin. Guangxi Acta Geol. Sin. 2007, 12, 1692-1697.

43. Hower, J.; Eslinger, E.V.; Hower, M.E.; Perry, E.A. Mechanism of burial metamorphism of argillaceous sediments: 1. Mineralogical and chemical evidence. Geol. Soc. Am. Bull. 1976, 5, 725-737. [CrossRef]

44. He, L.B. The relation between clay mineral variation of marine sediment cores and paleoclimate. Chin. Sci. Bull. 1982, 13, 809-812.

45. Yang, Z.S. Mineralogical assemblages and chemical characteristics of clays from sediments of the Huanghe, Changjiang, Zhujiang rivers and their relationship to the climate environment in their sediment source areas. Oceanol. Limnol. Sin. 1988, 4, 336-346.

46. Sun, G.Q.; Wang, Y.T.; Guo, J.J.; Wang, M.; Jiang, Y.; Pan, S.L. Clay Minerals and Element Geochemistry of Clastic Reservoirs in the Xiaganchaigou Formation of the Lenghuqi Area, Northern Qaidam Basin, China. Minerals 2019, 11, 678. [CrossRef]

47. Zhao, D.; He, P.; Kong, H.X.; Zheng, H.P.; Lei, Z.F. Characteristics and evolution of the clay minerals in Qaidam basin. Acta Sedimentol. Sin. 2001, 19, 66-70.

48. Singer, A. The paleoclimatic interpretation of clay minerals insediments: A review. Earth Sci. Rev. 1984, 21, 251-293. [CrossRef]

49. Zhang, Y.F.; Gao, D.L.; Liu, Y.; Miao, W.L.; Shi, L.; Li, B.L. Characteristics and environmental significance of clay minerals in the late Pieistocene sediment, Qaidam basin. Bull. Mineral. Petrol. Geochem. 2014, 33, 49-54.

50. Zhang, X.L. Relationship between carbon and oxygen stable isotope in carbonate rocks and paleosalinity and paleotemperature of sea water. Acta Sedimentol. Sin. 1985, 4, 17-30.

51. Shackleton, N.J. Attainmnet of isotopic equilibrium between ocean water and benthonic foraminifera genus Uvigerina: Isotopic changes in the ocean during the last glacial. Colloq. Int. CNRS (France) 1974, 219, $203-209$.

52. Keith, M.H.; Weber, J.N. Isotopic composition and environmental classification of selected limestones and fossils. Geochim. Cosmochim. Acta 1964, 28, 1787-1816. [CrossRef]

53. Wang, D.R. Stable Isotope Geochemistry of Oil and Gas; Petroleum Industry Press: Beijing, China, 2000; pp. 82-85.

54. Guo, H.L.; Wang, D.R. Stable isotopic composition and origin analysis of the carbonate cements with sandstone reservoir of Tarim oil-gas bearing area. Pet. Explor. Dev. 1999, 26, 31-34.

55. Nesbitt, H.W.; Young, G.M. Early Proterozoic climate and plate motion inferred from major element chemistry of lutites. Nature 1982, 299, 715-717. [CrossRef] 
56. Fedo, C.M.; Nesbitt, H.W.; Young, G.M. Unraveling the effects of potassium metasomatism in sedimentary rocks and paleosols, with implication for paleoweathering conditions and provenance. Geology 1995, 23, 921-924. [CrossRef]

57. Bauluz, B.; Mayayo, M.J.; Constanza, F.N.; Lopez, J.M.G. Geochemistry of Precambrian and Paleozoic siliciclastic rocks from the Iberian Range (NE Spain): Implications for source-area weathering, sorting, provenance, and tectonic setting. Chem. Geol. 2000, 168, 135-150. [CrossRef]

58. Rahman, M.J.J.; Suzuki, S. Geochemistry of sandstones from the Miocene Surma Group, Bengal Basin, Bangladesh: Implications for Provenance, tectonic setting and weathering. Geochem. J. 2007, 41, 415-428. [CrossRef]

59. Li, S.Y.; Yang, D.D.; Wang, S.; Wan, Q.; Wang, D.X. Characteristics of petrology, geochemistry, heavy minerals and isotope chronology of upper Carboniferous detrital rocks in the middle segment of south Tianshan and constraints to the provenance and tectonic evolution. Acta Geol. Sin. 2014, 88, 167-184.

60. Nesbitt, H.W.; Young, G.M. Prediction of some weathering trends of plutonic and volcanic rocks based on thermodynamic and kinetic considerations. Geochim. Cosmochim. Acta 1984, 48, 1523-1534. [CrossRef]

61. Nesbitt, H.W.; Young, G.M. Formation and diagenesis of weathering profiles. J. Geol. 1989, 97, $129-147$. [CrossRef]

62. Panahi, A.; Young, G.M.; Rainbird, R.H. Behavior of major and trace elements (including REE) during Paleoproterozoic pedogenesis and diagenetic alteration of an Archean granite near Ville Marie, Quebec, Canada. Geochim. Cosmochim. Acta 2000, 64, 2199-2220. [CrossRef]

63. McLennan, S.M. Weathering and global denudation. J. Geol. 1993, 101, 295-303. [CrossRef]

64. Young, G.M.; Long, D.G.F.; Fedo, C.M.; Nesbitt, H.W. Paleoproterozoic Huronian basin: Product of a Wilson cycle punctuated by glaciations and a meteorite impact. Sediment. Geol. 2001, 141-142, 233-254. [CrossRef]

65. Wang, C.S.; Li, X.H. Analysis Principle and Method of Sedimentary Basin; Higher Education Press: Beijing, China, 2003; p. 102.

66. Mclennan, S.M.; Hemming, S.; Mcdaniel, D.K.; Hanson, G.N. Geochemical approaches to sedimentation, provenance, and tectonics. Special Pap. Geol. Soc. Am. 1993, 284, 21-40. [CrossRef]

67. Boynton, W.V. Chapter 3-Cosmochemistry of the Rare Earth Elements: Meteorite Studies. Dev. Geochem. 1984, 2, 63-114. [CrossRef]

68. Bhatia, M.R.; Crook, K.A.W. Trace element characteristics of graywackes and tectonic setting discrimination of sedimentary basins. Contrib. Mineral. Petrol. 1986, 92, 181-193. [CrossRef]

69. Mclennan, S.M. Rare earth elements in sedimentary rocks: Influence of provenance and sedimentary processes. Rev. Mineral. Geochem. 1989, 21, 169-200. [CrossRef]

70. Bock, B.; Bahlburg, H.; Wörner, G.; Zimmermann, U. Tracing Crustal Evolution in the Southern Central Andes from Late Precambrian to Permian with Geochemical and $\mathrm{Nd}$ and Pb Isotope Data. J. Geol. 2000, 108, 515-535. [CrossRef]

71. Bhatia, M.R. Plate tectonics and geochemical composition of sandstones. J. Geol. 1983, 91, 611-627. [CrossRef]

72. Floyd, P.A.; Leverideg, B.E. Tectonic environment of the Devonian Gramscatho basin, south Cornwall: Framework mode and geochemical evidence from turbiditic sandstones. J. Geol. Soc. Lond. 1987, 144, 531-542. [CrossRef]

73. Armstrong-Altrin, J.S.; Verma, S.P. Critical evaluation of six tectonic setting discrimination diagrams using geochemical data of Neogene sediments from known tectonic settings. Sediment. Geol. 2005, 177, 115-129. [CrossRef]

74. Gao, D.; Cheng, R.H.; Shen, Y.J.; Wang, L.L.; Hu, X.Q. Southwestern Provenance-Sedimentary System and Provenance Tectonic Setting of Eastern Sag in the North Yellow Sea Basin. Earth Sci. 2016, 41, 1171-1187.

75. Song, L.J.; Liu, C.Y.; Zhao, H.G.; Wang, J.Q.; Zhang, X.L. Geochemical Characteristics, Sedimentary Environment and Tectonic Setting of Huangqikou Formation, Ordos Basin. Earth Sci. 2016, 41, 1295-1308.

76. Huang, Y.F.; Zhang, C.M.; Zhu, R.; Yi, X.F.; Qu, J.H.; Tang, Y. Palaeoclimatology, Provenance and Tectonic Setting during Late Permian to Middle Triassic in Mahu Sag, Junggar Basin, China. Earth Sci. 2017, 42, 1736-1749.

77. Ramkumar, M.; Santosh, M.; Nagarajan, R.; Li, S.S.; Mathew, M.J.; Menier, D.; Siddiqui, N.; Rai, J.; Sharma, A.; Farroqui, S.; et al. Late Middle Miocene volcanism in Northwest Borneo, Southeast Asia: Implications for tectonics, paleoclimate and stratigraphic marker. Palaeogeogr. Palaeoclimatol. Palaeoecol. 2018, 490, 141-162. [CrossRef] 
78. Huang, B.; Fu, D.; Kusky, T.M.; Ruan, K.P.; Zhou, W.X.; Zhang, X.H. Sedimentary provenance in response to Carboniferous arc-basin evolution of East Junggar and North Tianshan belts in the southwestern Central Asian Orogenic Belt. Tectonophysics 2018, 722, 324-341. [CrossRef]

79. Bhatia, M.R. Rare earth element geochemistry of Australian Paleozoic graywackes and mudrocks: Province and tectonic control. Sediment. Geol. 1985, 45, 97-113. [CrossRef]

80. McDonough, W.F.; Sun, S.S. The composition of the earth. Chem. Geol. 1995, 120, 223-253. [CrossRef]

81. Qin, X.F.; Xia, B.; Li, C.Q.; Li, J.; Lu, J.P.; Xu, H.; Zhou, F.S.; Hu, G.A.; Li, Q. Geochemical characteristics and tectonic setting of Precambrian granitic gneiss in the western segment of Altyn Tagh tectonic belt. Geoscience 2008, 22, 34-44.

82. Meng, F.C.; Zhang, J.X.; Yang, J.S. Subducted continental arc:Geochemical and isotopic evidence of gneisses in the north Qaidam. Acta Geol. Sin. 2005, 79, 46-55, (in Chinese with English abstract).

83. Wedepohl, K.H. Handbook of Geochemistry; Springer: Berlin, Germany, 1969; p. 248.

(C) 2020 by the authors. Licensee MDPI, Basel, Switzerland. This article is an open access article distributed under the terms and conditions of the Creative Commons Attribution (CC BY) license (http://creativecommons.org/licenses/by/4.0/). 